\title{
Comparative mitogenome analyses uncover mitogenome features and phylogenetic implications of the subfamily Cobitinae
}

\author{
Peng Yu ${ }^{1,2}$, Li Zhou ${ }^{1,2}$, Wen-Tao Yang ${ }^{1,2}$, Li-jun Miao ${ }^{1,2}$, Zhi Li $^{1}$, Xiao-Juan Zhang ${ }^{1}$, Yang Wang ${ }^{1,2^{*}}$ and \\ Jian-Fang Gui ${ }^{1,2^{*}}$ D
}

\begin{abstract}
Background: Loaches of Cobitinae, widely distributed in Eurasian continent, have high economic, ornamental and scientific value. However, the phylogeny of Cobitinae fishes within genera or family level remains complex and controversial. Up to now, about 60 Cobitinae mitogenomes had been deposited in GenBank, but their integrated characteristics were not elaborated.

Results: In this study, we sequenced and analyzed the complete mitogenomes of a female Cobits macrostigma. Then we conducted a comparative mitogenome analysis and revealed the conserved and unique characteristics of 58 Cobitinae mitogenomes, including C. macrostigma. Cobitinae mitogenomes display highly conserved tRNA secondary structure, overlaps and non-coding intergenic spacers. In addition, distinct base compositions were observed among different genus and significantly negative linear correlation between AT\% and AT-skew were found among Cobitinae, genus Cobitis and Pangio mitogenomes, respectively. A specific 3 bp insertion (GCA) in the atp8-atp6 overlap was identified as a unique feature of loaches, compared to other Cypriniformes fish. Additionally, all protein coding genes underwent a strong purifying selection. Phylogenetic analysis strongly supported the paraphyly of Cobitis and polyphyly of Misgurnus. The strict molecular clock predicted that Cobitinae might have split into northern and southern lineages in the late Eocene $(42.11 \mathrm{Ma})$, furthermore, mtDNA introgression might occur (14.40 Ma) between ancestral species of Cobitis and ancestral species of Misgurnus.
\end{abstract}

Conclusions: The current study represents the first comparative mitogenomic and phylogenetic analyses within Cobitinae and provides new insights into the mitogenome features and evolution of fishes belonging to the cobitinae family.

Keywords: Cobitinae, Loach, Mitochondrial genome, mtDNA introgression, Phylogeny, Divergence time

\footnotetext{
*Correspondence: wangyang@ihb.ac.cn; jfgui@ihb.ac.cn

${ }^{1}$ State Key Laboratory of Freshwater Ecology and Biotechnology, Institute of Hydrobiology, the Innovation Academy of Seed Design, Chinese Academy of Sciences, Wuhan 430072, China

Full list of author information is available at the end of the article
}

(C) The Author(s). 2021 Open Access This article is licensed under a Creative Commons Attribution 4.0 International License, which permits use, sharing, adaptation, distribution and reproduction in any medium or format, as long as you give appropriate credit to the original author(s) and the source, provide a link to the Creative Commons licence, and indicate if changes were made. The images or other third party material in this article are included in the article's Creative Commons licence, unless indicated otherwise in a credit line to the material. If material is not included in the article's Creative Commons licence and your intended use is not permitted by statutory regulation or exceeds the permitted use, you will need to obtain permission directly from the copyright holder. To view a copy of this licence, visit http://creativecommons.org/licenses/by/4.0/. The Creative Commons Public Domain Dedication waiver (http://creativecommons.org/publicdomain/zero/1.0/) applies to the data made available in this article, unless otherwise stated in a credit line to the data. 


\section{Background}

Vertebrate mitogenome is a small $(16-17 \mathrm{~kb})$ and circular double-stranded molecule [1]. It contains 37 genes including 22 tRNA genes, 13 PCGs and two rRNA genes [1]. It also has two noncoding regions, $\mathrm{O}_{\mathrm{L}}$ and $\mathrm{CR}$, and the latter contains regulatory elements for controlling the transcription and replication of mtDNA molecule [2, 3 ]. Due to its unique features, such as high copy numbers in tissues, simple genomic organization, maternal inheritance, almost unambiguous orthology, haploid inheritance and high nucleotide substitution rate [4-6], mitogenome has been widely applied in species identification, i.e., DNA barcoding, as well as population genetics, conservation biology, molecular phylogenetics and evolutionary processes [7-13]. Gene arrangements of fish mitogenomes are generally conserved, only with a few exceptions [1]. However, the genome sequence length, the bias of base composition and start/stop codon, the overlap and IGSs are diverse among different species [14].

Cobitinae is a subfamily of Cobitidae that was first identified by Hora (1932). To date, it contains 214 species recorded in FishBase, covering 21 genera, such as Cobits, Misgurnus and Paramisgurnus [15]. Loaches of subfamily Cobitinae are bottom-dwelling fishes and widely distributed in Eurasian continent. They usually possess high economic, ornamental and scientific research value. Loach commercial farming, including cobitid loach (M. anguillicaudatus) and large-scale loach ( $P$. dabryanus), occupies a significant position in freshwater aquaculture of Asia, due to their enjoyable taste, high nutritional value, rapid growth and strong adaptation [16-18]. In China, loach is used as a diet therapy or folk remedy for patient's recovery or treatment of many diseases, such as hepatitis, osteomyeitis, carbuncles, and cancers. Many Cobitis populations are mixed diploid-polyploid, even bisexual and unisexual forms co-existing in the same niche [19-21]. They are suitable as models to reveal the relationship among hybridization, polyploidization, reproduction, speciation and evolution [21-23]. Due to their great diversity, they are also used to trace the biogeographic history of freshwater systems and to reflect geologic events [24]. Cobitinae fishes usually inhabit various benthic habitats in rivers, lakes, streams and ponds [25]. However, dilapidation of the ecological environment has led to a decrease of benthic organisms [26, 27]. Cobitinae fishes are seriously threatened and their wild populations are gradually decreasing [28]. On this account, the diversity of these benthic fishes have been used as a bioindicator to assess the quality of the ecological environment [29, 30]. In addition, many Cobitinae species, such as the "kuhli loaches", are well-known in Southeast Asia and Europe as ornamental fish for their varied morphological patterns and the ability to ingest bottom organic residues.

Cobitinae fishes are difficult to be classified because of their morphological similarity and high plasticity in morphology [31]. Although the secondary sexual dimorphism is used to define genera, it is not always congruent with the current genera definitions. The molecular phylogeny of Cobitinae fishes has been studied at the genera or family level via one or two mitochondrial and/or nuclear genes [24, 31-36], and remains complex and controversial. For example, based on mitochondrial gene $c y t b$ and nuclear gene rag-1, Perdices et al. (2016) [37] reconstructed the phylogenetic relationship of Northern Clade of family Cobitidae that inhabit in Europe, and North and Northwest parts of Asia. The subfamily Cobitinae was divided into Cobitis sensu lato group (Cobitis, Iksookimia, Niwaella and Kichulchoia), Misgurnus sensu lato group (Misgurnus, Paramisgurnus and Koreocobitis), Microcobitis, and Sabanejewia. Although the monophyly of the groups were resolved, the relationships within the groups are discordant with current taxonomic status.

Up to now, about 60 mitogenomes, covering more than 40 species of Cobitinae, have been deposited into GenBank [38-55]. Although a few mitogenomes characteristics were described, the integrated characteristics of Cobitinae mitogenomes are still not well known. In this study, we sequenced the mitogenome of C. macrostigma, the type species of the genus Cobitis [25], and compared it with other 41 species (57 individuals) to amplify detailed features of the Cobitinae mitogenomes. Additionally, we assembled a large sequence matrix (11,442 bp) of 58 Cobitinae mitogenomes and two outgroups to investigate the phylogenetic status and the origin time of Cobitinae fishes.

\section{Results}

\section{General features of $C$. macrostigma mitogenome}

The mitogenome of C. macrostigma was sequenced, annotated and compared with 57 Cobitinae mitogenomes (Table 1). It contains 13 PCGs (nd1-6, nd4l, cox1-3, cytb, atp6 and atp8), 22 tRNA genes, two rRNA genes (12S $r R N A$ and $16 S$ rRNA) and two non-coding regions $\left(\mathrm{O}_{\mathrm{L}}\right.$ and $\left.\mathrm{CR}\right)$ (GenBank: MT259034). Gene order and orientation are same to most teleost mitogenomes (Fig. 1, Table 2). PCGs range from $168 \mathrm{bp}$ (atp8) to $1551 \mathrm{bp}$ $(\operatorname{cox} 1)$ in size, with a total length of 11,427 bp. tRNAs vary from $66 \mathrm{bp}\left(t R N A^{C y s}(C)\right)$ to $76 \mathrm{bp}\left(t R N A^{L y s}(K)\right)$ in size, with a total length of $1557 \mathrm{bp}$. The length of small encoding subunit $12 S$ rRNA and large subunit $16 S$ rRNA are $952 \mathrm{bp}$ and $1675 \mathrm{bp}$, respectively. They are flanked by $t R N A^{\text {Phe }}$ and $t R N A^{\text {Leu(UUR) }}$ and interposed by $t R N A$ Val. Among 58 mitogenomes analyzed, the entire mitogenome of C. macrostigma has the highest (99.6\%) 
Table 1 Species, GenBank accession number and length of mitogenomes used in this study

\begin{tabular}{|c|c|c|c|c|c|}
\hline & Genus & Species & Accession ID & Sequence length (bp) & Reference \\
\hline 1 & Cobitis & Cobitis macrostigma & MT259034 & 16,636 & this study \\
\hline 2 & Acantopsis & Acantopsis choirorhynchos & AB242161.1 & 16,600 & [38] \\
\hline 3 & Acanthopsoides & Acanthopsoides gracilentus & NC_029438.1 & 16,603 & Unpublished \\
\hline 4 & Canthophrys & Canthophrys gongota & NC_031576.1 & 16,561 & Unpublished \\
\hline 5 & Cobitis & Cobitis biwae & NC_027663.1 & 16,642 & [39] \\
\hline 6 & Cobitis & Cobitis choii & NC_010649.2 & 16,566 & {$[40]$} \\
\hline 7 & Cobitis & Cobitis elongatoides & NC_023947.1 & 16,541 & [41] \\
\hline 8 & Cobitis & Cobitis granoei & NC_023473.1 & 16,636 & {$[42]$} \\
\hline 9 & Cobitis & Cobitis lutheri & NC_022717.1 & 16,639 & Unpublished \\
\hline 10 & Cobitis & Cobitis minamorii minamorii & AP013309.1 & 16,645 & Unpublished \\
\hline 11 & Cobitis & Cobitis matsubarai & NC_029441.1 & 16,636 & Unpublished \\
\hline 12 & Cobitis & Cobitis nalbanti & MH349461.1 & 16,631 & [43] \\
\hline 13 & Cobitis & Cobitis sp. (1) & AP013307.1 & 16,571 & Unpublished \\
\hline 14 & Cobitis & Cobitis sp. (2) & AP013306.1 & 16,570 & Unpublished \\
\hline 15 & Cobitis & Cobitis sp. (3) & AP013296.1 & 16,576 & Unpublished \\
\hline 16 & Cobitis & Cobitis striata (1) & AP010782.1 & 16,646 & [44] \\
\hline 17 & Cobitis & Cobitis striata (2) & AB054125.1 & 16,572 & {$[45]$} \\
\hline 18 & Cobitis & Cobitis striata striata & AP013311.1 & 16,631 & Unpublished \\
\hline 19 & Cobitis & Cobitis sinensis & NC_007229.1 & 16,553 & Unpublished \\
\hline 20 & Cobitis & Cobitis takatsuensis (1) & AP009306.1 & 16,647 & [44] \\
\hline 21 & Cobitis & Cobitis takatsuensis (2) & AP011290.1 & 16,578 & [39] \\
\hline 22 & Iksookimia & Iksookimia longicorpa & NC_027850.1 & 16,624 & Unpublished \\
\hline 23 & Kichulchoia & Kichulchoia multifasciata & AP011337.1 & 16,643 & Unpublished \\
\hline 24 & Koreocobitis & Koreocobitis naktongensis & HM535625.1 & 16,567 & Unpublished \\
\hline 25 & Kottelatlimia & Kottelatlimia pristes & NC_031597.1 & 16,588 & Unpublished \\
\hline 26 & Lepidocephalichthys & Lepidocephalichthys annandalei & AP013313.1 & 16,337 & Unpublished \\
\hline 27 & Lepidocephalichthys & Lepidocephalichthys guntea & NC_031593.1 & 16,567 & Unpublished \\
\hline 28 & Lepidocephalichthys & Lepidocephalichthys hasselti & AP013334.1 & 15,897 & Unpublished \\
\hline 29 & Lepidocephalichthys & Lepidocephalichthys micropogon & NC_031595.1 & 16,608 & Unpublished \\
\hline 30 & Lepidocephalichthys & Lepidocephalichthys sp. & AP013314.1 & 15,917 & Unpublished \\
\hline 31 & Lepidocephalus & Lepidocephalus macrochir & NC_031596.1 & 16,556 & Unpublished \\
\hline 32 & Misgurnus & Misgurnus anguillicaudatus (1) & KC823274.1 & 16,646 & {$[46]$} \\
\hline 33 & Misgurnus & Misgurnus anguillicaudatus (2) & KM186181.1 & 16,645 & Unpublished \\
\hline 34 & Misgurnus & Misgurnus anguillicaudatus (3) & KC881110.1 & 16,643 & [47] \\
\hline 35 & Misgurnus & Misgurnus anguillicaudatus (4) & KC734881.1 & 16,643 & [48] \\
\hline 36 & Misgurnus & Misgurnus anguillicaudatus (5) & KC884745.1 & 16,644 & [47] \\
\hline 37 & Misgurnus & Misgurnus anguillicaudatus (6) & MG938590.1 & 16,646 & Unpublished \\
\hline 38 & Misgurnus & Misgurnus anguillicaudatus (7) & KC509900.1 & 16,646 & [49] \\
\hline 39 & Misgurnus & Misgurnus anguillicaudatus (8) & MF579257.1 & 16,647 & Unpublished \\
\hline 40 & Misgurnus & Misgurnus anguillicaudatus (9) & KC509901.1 & 16,646 & [49] \\
\hline 41 & Misgurnus & Misgurnus anguillicaudatus (10) & KC762740.1 & 16,645 & {$[46]$} \\
\hline 42 & Misgurnus & Misgurnus anguillicaudatus (11) & HM856629.1 & 16,634 & {$[50]$} \\
\hline 43 & Misgurnus & Misgurnus anguillicaudatus (12) & AP011291.1 & 16,641 & [39] \\
\hline 44 & Misgurnus & Misgurnus anguillicaudatus (13) & DQ026434.1 & 16,565 & {$[51]$} \\
\hline
\end{tabular}


Table 1 Species, GenBank accession number and length of mitogenomes used in this study (Continued)

\begin{tabular}{llllll}
\hline & Genus & Species & Accession ID & Sequence length (bp) & Reference \\
\hline 45 & Misgurnus & Misgurnus anguillicaudatus (14) & NC_011209.1 & 16,565 & {$[51]$} \\
46 & Misgurnus & Misgurnus bipartitus & NC_022854.1 & 16,636 & {$[52]$} \\
47 & Misgurnus & Misgurnus mizolepis & NC_038151.1 & 16,571 & Unpublished \\
48 & Misgurnus & Misgurnus mohoity & KF386025.1 & 16,566 & {$[53]$} \\
49 & Misgurnus & Misgurnus nikolskyi & AB242171.1 & 16,570 & [38] \\
50 & Niwaella & Niwaella delicata & AP009308.1 & 16,571 & [44] \\
51 & Paramisgurnus & Paramisgurnus dabryanus (1) & KR349175.1 & 16,570 & [54] \\
52 & Paramisgurnus & Paramisgurnus dabryanus (2) & AP012124.1 & 16,571 & Unpublished \\
53 & Paramisgurnus & Paramisgurnus dabryanus (3) & K027397.1 & 16,570 & [38] \\
54 & Pangio & Pangio anguillaris & AB242168.1 & 16,602 & Unpublished \\
55 & Pangio & Pangio cuneovirgata & NC_031594.1 & 16,596 & Unpublished \\
56 & Pangio & Pangio kuhlii & NC_031599.1 & 16,601 & Unpublished \\
57 & Pangio & NC_031592.1 & 16,600 & Unpublished \\
58 & Microcobitis & Pangio oblonga & AP013297.1 & 16,549 & [15] \\
59 & Sinorhodeus & Microcobitis sp. & MH190825 & 16,591 & KF176560.1 \\
60 & Rhodeus & Rhorhodeus microlepis & 16,774 & \\
\hline
\end{tabular}

similarity with C. granoei and lowest (88.2\%) with $C$. sinensis.

\section{Highly conserved tRNAs secondary structure, overlaps and non-coding intergenic spacers among Cobitinae mitogenomes}

Cobitinae mitogenomes range from 16,337 bp (L. annandalei) to $16,647 \mathrm{bp}$ ( $M$. anguillicaudatus and $C$. takatsuensis) in length (Table 1). Their gene composition, gene arrangement and strand bias are highly conserved (Fig. 1 and Table 2). Among the 22 tRNAs, due to the absence of DHU arm, $t R N A^{\operatorname{ser}(A G N)}(S 1)$ is the only one that is not folded into the typical clover-leaf secondary structure (Fig. 2a). In the Cobitinae mitogenomes, unmatched base pairs are widespread among tRNAs. Taking C. macrostigma as an example, there are 446 base pairs among the 22 tRNAs, and only one gene ( $t R N A^{\text {Leu(- }}$ ${ }^{C U N)}$ ) possesses a fully paired stem. In the 425 base pairs of other 21 tRNAs, there are 43 (10.1\%) unmatched base pairs that contain 28 noncanonical matches of G-U and 15 other mismatches, including A-C (7), A-A (1), C-C (2), C-U (2), and U-U (3) (Fig. 2a). Most of them are located in the acceptor, DHU and anticodon stems.

We also compared the gene overlaps and IGSs among 58 Cobitinae mitogenomes. Two long overlaps (atp8atp6 and nd4l-nd4) and two long IGSs $\left(\mathrm{O}_{\mathrm{L}}\right.$ and $t R N A^{A s p}$-cox2) were found in Cobitinae mitogenomes. Highly conserved motifs "ATGCTAA" and "ATGGCAATAA" were found in the overlapped junctions between $n d 4 l$ and $n d 4$, and between atp 8 and atp6, respectively (Fig. 3a). There are also several small overlaps between adjacent tRNA genes, such as $t R N A^{\text {Ile }}-t R N A^{G l n}$ and $t R N A^{T h r}-t R N A^{\text {Pro }} . \mathrm{O}_{\mathrm{L}}$ is located within the five gene cluster (WANCY) (Table 2, Fig.1) and its secondary structure shows a stable stem-loop hairpin, which is strengthened by six C-G base pairs (Fig. 2b). Among the $31 \mathrm{bp}$ of $\mathrm{O}_{\mathrm{L}}$, the $\mathrm{C}-\mathrm{G}$ base pairs on stems are highly conserved while the loops in the middle are variable (Fig. $3 \mathrm{~b})$. Another long IGS, between $t R N A^{A s p}$ and $\operatorname{cox} 2$, is also conserved in the $5^{\prime}$ and $3^{\prime}$ end, and highly variable in the middle.

$\mathrm{CR}$, located between $t R N A^{\text {Pro }}$ and $t R N A^{\text {Phe }}$, is the most variable region in Cobitinae mitogenomes and ranges from $872 \mathrm{bp}$ (Lepidocephalus macrochir) to $990 \mathrm{bp}$ ( $C$. takatsuensis) (Supplementary Table 2) [44]. Three domains are conserved and can be recognized in Cobitinae mitogenomes (Fig. 3c). They are terminal associated sequences (TAS), the central conserved-blocks (CSB-D, CSB-E and CSB-F) and conserved sequence blocks (CSB-1, CSB - 2 and CSB-3).

\section{Usage bias of start and stop codon, codon distributions and relative synonymous codons in Cobitinae mitogenomes}

The typical start codon ATG is conservative and is used in 12 PCGs, while GTG is only used in cox1 in 98\% (57/ 58) analyzed Cobitinae mitogenomes except one individual of M. anguillicaudatus (No. 11) (Fig. 4, Supplementary Table 3). Five types of stop codons were found, containing three canonical (TAA, TAG and AGA) and two truncated stop codons (TA- and T--) (Fig. 4). The two truncated termination codons are used in $n d 2, \operatorname{cox} 2$, 


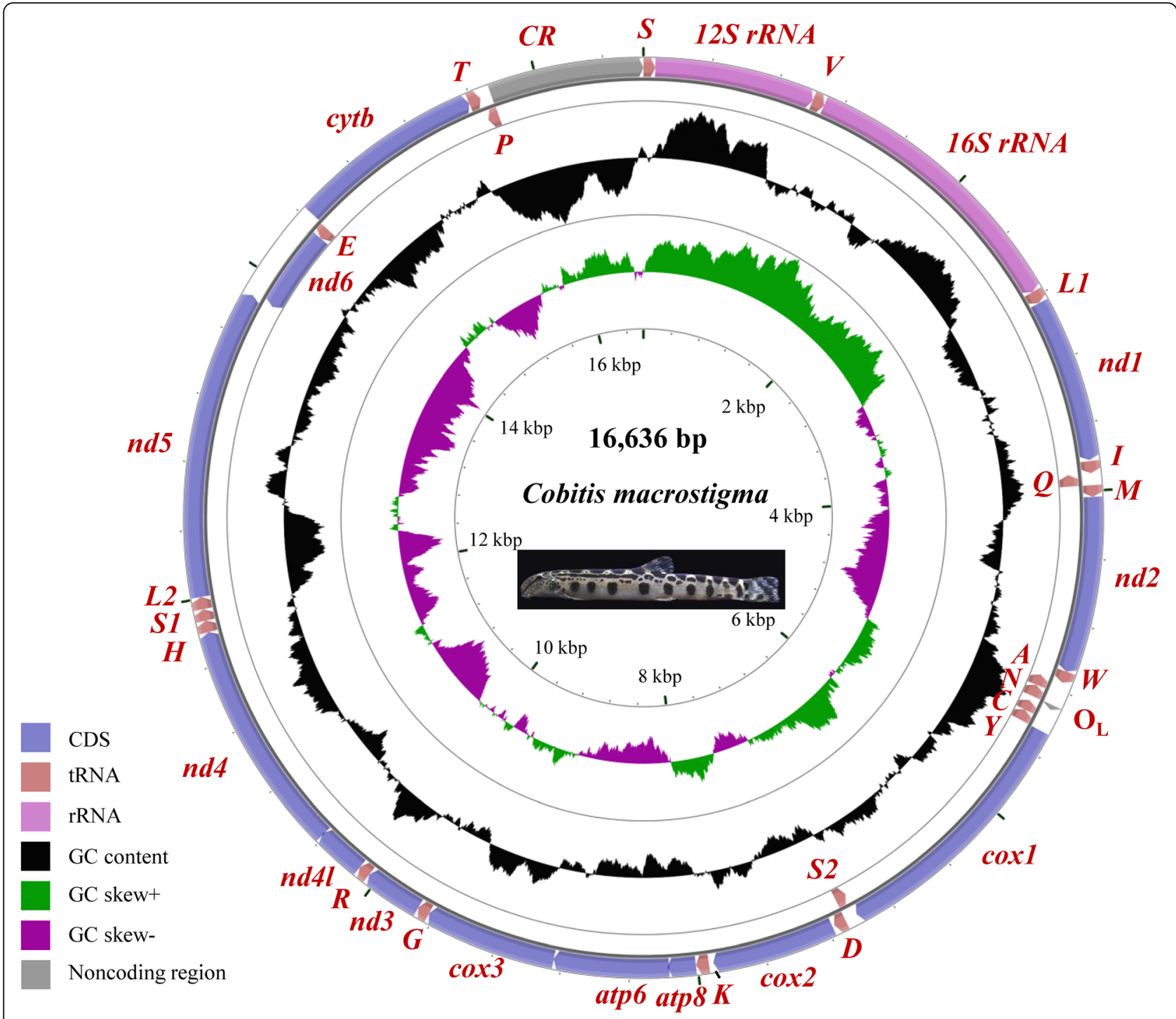

Fig. 1 Circular sketch map of the C. macrostigma mitogenome. Different colors represent different gene blocks

atp6, cox3, nd3, nd4 and cytb, the 3' -ends of which are followed by a tRNA gene encoded with the same strand.

The codon distribution and relative synonymous codon usage (RSCU) of 58 Cobitinae mitogenomes were analyzed. Our results show that codon distribution is largely coincident among these Cobitinae mitogenomes (Supplementary Figure S1). As shown by six representative species of Cobitinae, the codons encoding Leu ${ }^{(\mathrm{CUN})}$, Ala and Thr are the three most frequently present, while those encoding Cys are rare (Fig. 5a). Compared to the other five Cobitinae species, $P$. anguillaris uses more codons of $L e u^{(C U N)}$ and less codons of $L e u^{(U U R)}$. The patterns of RSCU are also consistent among the analyzed species (Fig. 5b). Degenerated codons are biased to use more $\mathrm{A} / \mathrm{T}$ than $\mathrm{G} / \mathrm{C}$ in the 3rd position of PCGs, which results in the content of $A+T$ is higher than $G+C$ in the 3rd position of Cobitinae PCGs. For example, the codons for Arginine CCA and the codes for Tryptophan UGU are prevalent, while their other synonymous codons are relatively less used.

\section{$\mathrm{A}+\mathrm{T} \%$, AT-skew and their linear correlations of Cobitinae mitogenomes}

The A + T content and AT-skew of whole mitogenomes, PCGs, tRNAs, rRNAs and CR were calculated (Fig. 6ab). The 58 Cobitinae mitogenomes all exhibit AT bias, and the $\mathrm{A}+\mathrm{T}$ content is the lowest $(54.8 \pm 0.6 \%)$ in tRNAs and the highest $(66.3 \pm 0.9 \%)$ in CR (Fig. 6a, Supplementary Table 2). The AT-skew values are the largest and positive in rRNAs, while they are the smallest in 
Table 2 Annotation of the C. macrostigma mitogenome

\begin{tabular}{|c|c|c|c|c|c|c|c|c|}
\hline Feature & Position & $\begin{array}{l}\text { Nucleotide size } \\
\text { (bp) }\end{array}$ & $\begin{array}{l}\text { Start } \\
\text { codon }\end{array}$ & $\begin{array}{l}\text { Stop } \\
\text { codon }\end{array}$ & $\begin{array}{l}\text { Amino } \\
\text { acid }\end{array}$ & $\begin{array}{l}\text { Anti- } \\
\text { codon }\end{array}$ & $\begin{array}{l}\text { Intergenic } \\
\text { nucleotide }^{a}\end{array}$ & Strand $^{\mathbf{b}}$ \\
\hline tRNA ${ }^{\text {Phe }}(S)$ & $1-69$ & 69 & & & & GAA & 0 & $\mathrm{H}$ \\
\hline 125 rRNA & 70-1021 & 952 & & & & & 0 & $\mathrm{H}$ \\
\hline tRNA $A^{V a l}(V)$ & 1022-1093 & 72 & & & & TAC & 0 & $\mathrm{H}$ \\
\hline 165 rRNA & $1094-2768$ & 1675 & & & & & 0 & $\mathrm{H}$ \\
\hline $\operatorname{tRNA} A^{\operatorname{Leu}(U \cup R)}(L 1)$ & 2769-2843 & 75 & & & & TAA & 1 & $\mathrm{H}$ \\
\hline ndl & 2845-3819 & 975 & ATG & TAA & 324 & & 6 & $\mathrm{H}$ \\
\hline tRNA $A^{\| l e}(I)$ & $3826-3897$ & 72 & & & & GAT & -2 & $\mathrm{H}$ \\
\hline $\operatorname{tRNA} A^{G \ln }(Q)$ & 3896-3966 & 71 & & & & TTG & 1 & L \\
\hline$t R N A^{M e t}(M)$ & $3968-4036$ & 69 & & & & CAT & 0 & $\mathrm{H}$ \\
\hline$n d 2$ & $4037-5081$ & 1045 & ATG & $\mathrm{T}$ & 348 & & 0 & $\mathrm{H}$ \\
\hline $\operatorname{tRNA} A^{T r p}(W)$ & $5082-5151$ & 70 & & & & TCA & 1 & $\mathrm{H}$ \\
\hline $\operatorname{tRNA} A^{A l a}(A)$ & $5153-5221$ & 69 & & & & TGC & 1 & L \\
\hline 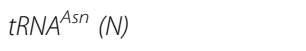 & $5223-5295$ & 73 & & & & $\mathrm{GTT}$ & 0 & L \\
\hline $\begin{array}{l}\text { L-strand replication origin } \\
\left(\mathrm{O}_{\mathrm{L}}\right)\end{array}$ & $5296-5325$ & 30 & & & & & 0 & \\
\hline $\operatorname{tRNA} A^{C y s}(C)$ & $5326-5391$ & 66 & & & & GCA & 0 & $\mathrm{~L}$ \\
\hline $\operatorname{tRN} A^{T y r}(Y)$ & $5392-5460$ & 69 & & & & GTA & 1 & $\mathrm{~L}$ \\
\hline $\operatorname{cox} 1$ & $5462-7012$ & 1551 & GTG & TAA & 516 & & 1 & $\mathrm{H}$ \\
\hline $\operatorname{tRN} A^{\operatorname{Ser}(U C N)}(\mathrm{S} 2)$ & 7014-7084 & 71 & & & & TGA & 2 & $\mathrm{~L}$ \\
\hline 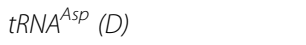 & $7087-7158$ & 72 & & & & GTC & 13 & $\mathrm{H}$ \\
\hline $\cos 2$ & $7172-7906$ & 735 & ATG & TAA & 244 & & 26 & $\mathrm{H}$ \\
\hline $\operatorname{tRNA} A^{\text {Lys }}(\mathrm{K})$ & $7933-8008$ & 76 & & & & $\pi T$ & 1 & $\mathrm{H}$ \\
\hline atp8 & $8010-8177$ & 168 & ATG & TAA & 55 & & -10 & $\mathrm{H}$ \\
\hline atp6 & $8168-8851$ & 684 & ATG & TAA & 227 & & -1 & $\mathrm{H}$ \\
\hline $\operatorname{cox} 3$ & $8851-9634$ & 784 & ATG & $\mathrm{T}$ & 261 & & 0 & $\mathrm{H}$ \\
\hline $\operatorname{tRNA} A^{G l y}(G)$ & $9635-9706$ & 72 & & & & TCC & 0 & $\mathrm{H}$ \\
\hline nd3 & $9707-10,055$ & 349 & ATG & $\mathrm{T}$ & 116 & & 0 & $\mathrm{H}$ \\
\hline$t R N A^{\operatorname{Arg}}(R)$ & $\begin{array}{l}10,056-10 \\
125\end{array}$ & 70 & & & & TCG & 0 & $\mathrm{H}$ \\
\hline$n d 41$ & $\begin{array}{l}10,126-10 \\
422\end{array}$ & 297 & ATG & TAA & 98 & & -7 & $\mathrm{H}$ \\
\hline$n d 4$ & $\begin{array}{l}10,416-11 \\
797\end{array}$ & 1382 & ATG & TA & 460 & & 0 & $\mathrm{H}$ \\
\hline $\operatorname{tRNA} A^{\text {His }}(\mathrm{H})$ & $\begin{array}{l}11,798-11 \\
866\end{array}$ & 69 & & & & GTG & 0 & $\mathrm{H}$ \\
\hline $\operatorname{tRNA} A^{\operatorname{Ser}(A G Y)}(S 1)$ & $\begin{array}{l}11,867-11 \\
934\end{array}$ & 68 & & & & $\mathrm{GCT}$ & 1 & $\mathrm{H}$ \\
\hline $\operatorname{tRNA} A^{\operatorname{Leu}(C U N)}($ L2) & $\begin{array}{l}11,936-12 \\
008\end{array}$ & 73 & & & & TAG & 0 & $\mathrm{H}$ \\
\hline nd5 & $\begin{array}{l}12,009-13 \\
847\end{array}$ & 1839 & ATG & TAG & 612 & & -4 & $\mathrm{H}$ \\
\hline nd6 & $\begin{array}{l}13,844-14 \\
365\end{array}$ & 522 & ATG & TAA & 173 & & 0 & $\mathrm{~L}$ \\
\hline$t R N A^{G / u}(E)$ & $\begin{array}{l}14,366-14 \\
434\end{array}$ & 69 & & & & $\pi \mathrm{TC}$ & 6 & L \\
\hline cytb & $\begin{array}{l}14,441-15 \\
581\end{array}$ & 1141 & ATG & $\mathrm{T}$ & 380 & & 0 & $\mathrm{H}$ \\
\hline
\end{tabular}


Table 2 Annotation of the C. macrostigma mitogenome (Continued)

\begin{tabular}{|c|c|c|c|c|c|c|c|c|}
\hline Feature & Position & $\begin{array}{l}\text { Nucleotide size } \\
\text { (bp) }\end{array}$ & $\begin{array}{l}\text { Start } \\
\text { codon }\end{array}$ & $\begin{array}{l}\text { Stop } \\
\text { codon }\end{array}$ & $\begin{array}{l}\text { Amino } \\
\text { acid }\end{array}$ & $\begin{array}{l}\text { Anti- } \\
\text { codon }\end{array}$ & $\begin{array}{l}\text { Intergenic } \\
\text { nucleotide }^{a}\end{array}$ & Strand $^{b}$ \\
\hline tRNA ${ }^{T h r}(T)$ & $\begin{array}{l}15,582-15 \\
653\end{array}$ & 72 & & & & TGT & -2 & $\mathrm{H}$ \\
\hline tRNA $A^{\text {Pro }}(P)$ & $\begin{array}{l}15,652-15 \\
721\end{array}$ & 70 & & & & TGG & -2 & L \\
\hline Control region (CR) & $\begin{array}{l}15,720-16, \\
636\end{array}$ & 917 & & & & & & \\
\hline
\end{tabular}

PCGs and most are negative except Canthophrys gongota, Acantopsis choirorhynchos, P. cuneovirgata, P. kuhlii, P. oblonga, and Kottelatlimia pristes (Fig. 6, Supplementary Table 2). These results indicate that PCGs are biased towards using $\mathrm{T}$ not $\mathrm{A}$ in most Cobitinae mitogenomes. To examine whether the $\mathrm{A}+\mathrm{T}$ content and AT-skew are different in three codon position of PCGs, we also selected the six Cobitinae species for a more detailed analysis. The $\mathrm{A}+\mathrm{T}$ content shows 1 st $<$ 2nd $<3$ rd in the three position of PCGs in all analyzed fishes. Meanwhile, the AT-skew of 1st and 3rd are positive while 2 nd is negative (Table 3 ). This is due to the bias usage of relative synonymous codons (Fig. 5b). In all analyzed Cobitinae mitogenomes, CRs possess more A and $\mathrm{C}$ with all AT-skew values positive $(0.002-0.112)$ and GC-skew negative $(-0.341--0.101)$ (Supplementary Table 2).

The correlations of Cobitinae mitogenomes $\left(\mathrm{y}_{\mathrm{A} 1}=-\right.$ $\left.0.0166 \mathrm{x}-0.9047, \mathrm{R}^{2}=0.5991\right)$ genus Cobits $\left(\mathrm{y}_{\mathrm{A} 2}=-\right.$ $0.012 \mathrm{x}+0.5786, \mathrm{R}^{2}=0.5197$ ) and Pangio $\left(\mathrm{y}_{\mathrm{A} 3}==\right.$ $\left.0.0466 x+2.5813, R^{2}=0.5486\right)$ were calculated between $\mathrm{A}+\mathrm{T} \%$ versus AT-skew. All of them showed negative linear correlations, implying that AT-skew becomes more positive with the increasing of $\mathrm{A}+\mathrm{T}$ content (Fig. $6 \mathrm{c}$ ). The similar negative linear correlations were also found in $\mathrm{G}+$ C \% versus GC-skew (Fig. 6d).

\section{Non-synonymous and synonymous substitutions}

To better understand the role of selective pressure and evolutionary relations of Cobitinae fishes, the $\omega$ or $\mathrm{dN} /$ dS value of each PCG was calculated (Fig. 7). All the PCGs evolved under a purifying selection $(\omega<0.5)$. The atp 8 gene showed the highest $\omega$ value $(\omega=0.12)$ and the cox family genes were lowest $(\omega=0.02 \pm 0.01)$. This phenomenon is also found in most Metazoa [56], but the fold change (>10 fold) is particularly high in Cobitinae. The lower $\omega$ value represents less variations in amino acids. Thus, $c o x 1, \operatorname{cox} 3$ and $c y t b$ are potential barcoding markers for Cobitinae species identification.

\section{Phylogenetic analysis of Cobitinae fishes}

Molecular phylogenetic analyses were performed using 13 PCGs from 58 Cobitinae mitogenomes, belonging to
41 species from 14 genera. The ML and BI analyses generated similar topology with high bootstrap support / posterior probability values. Each tree was similarly divided into two main clades: Cobitis-Misgurnus-other genera (clade I) and Pangio-Lepidocephalichthys-other genera (clade II) (Fig. 8 and Supplementary Figure S2). Clade I included all analyzed species of Cobitis, Paramisgurnus and Misgurnus, and five species from other genus (I. longicorpa, K. multifasciata, N. delicata, K. naktongensis, and Microcobitis sp.). Four Pangio species, five Lepidocephalichthys species and other five species (K. pristes, A. choirorhynchos, A. gracilentus, L. macrochir, and C. gongota) were clustered into Clade II, among which the analyzed species of genus Pangio and Lepidocephalichthys formed two well-supported $(\mathrm{pp}=1.00)$ monophyletic groups respectively. In addition, Pangio is the sister genus to Lepidocephalichthys.

The BI phylogenetic tree confirmed that Cobitis was a paraphyletic group, since Misgurnus clade A, N. delicate, I. longicorpa, and $K$. multifasciata shared the common ancestor with the all 15 Cobitis species analyzed in this study, with high posterior probability values $(\mathrm{pp}=1.00)$. The species of Misgurnus were separated into two independent lineages: the majority of $M$. anguillicaudatus individuals (12/14) and $M$. bipartitus clustering with the Cobitis species (Misgurnus clade A), and two M. anguillicaudatus individuals, $M$. mizolepis, $M$. mohoity, and $M$. nikolskyi gathering with $P$. dabryanus and $K$. naktongensis (Misgurnus clade B).

\section{Divergence time estimation of Cobitinae fishes}

The combination of strict clock model and Yule process tree prior provided the best fit to the data sets (Supplementary Table 4). The chronogram with divergence time of Cobitinae lineages was estimated based on the cytB mutation rate $(0.68 \%$ per million years) (Fig. 9). The first split of Cobitinae lineages was estimated to have occurred in the late Eocene (42.11 Ma, 95\% HPD: 36.35$47.86 \mathrm{Ma}$ ), then separated into clade I (northern clade) and clade II (southern lineages). Cobitis-IksookimiaKichulchoia-Niwaella lineage diverged from the rest of northern clade lineage during the Oligocene (30.07 Ma, 95\% HPD: $25.55-34.69 \mathrm{Ma})$, similar to the previous 


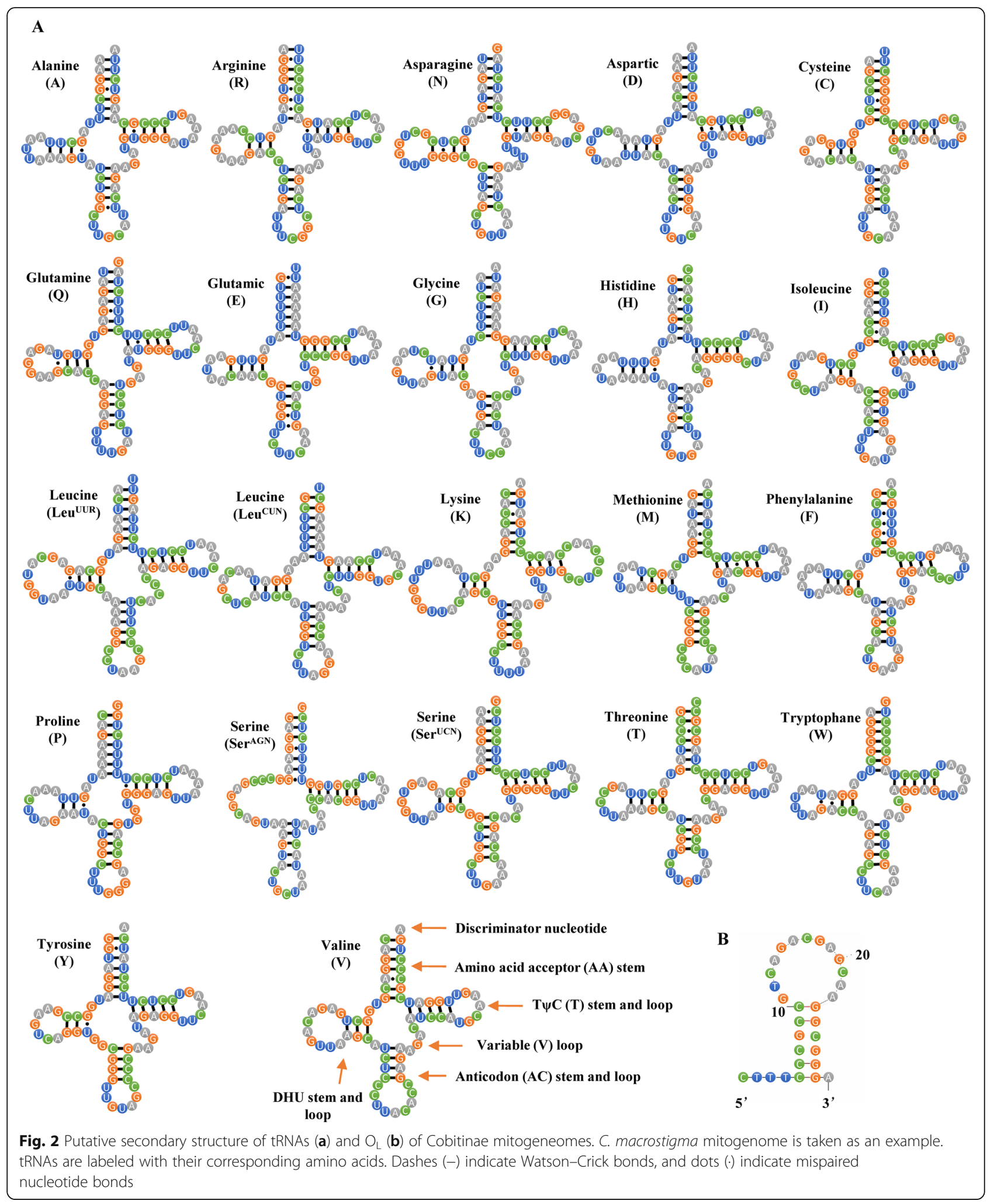

described [35], then diversified and further radiated after 4.94 Ma. The mtDNA introgression between ancestral species of Cobitis and ancestral species of Misgurnus seems to have taken place in the Middle Miocene (14.40
Ma, 95\% HPD: 12.30-16.54 Ma). C. macrostigma appeared about $0.36 \mathrm{Ma}$ (95\% HPD: $0.06-0.55 \mathrm{Ma}$ ) in the Pleistocene. Pangio-Lepidocephalichthys-other genera (southern lineages) might originate about $40.45 \mathrm{Ma}$. In 


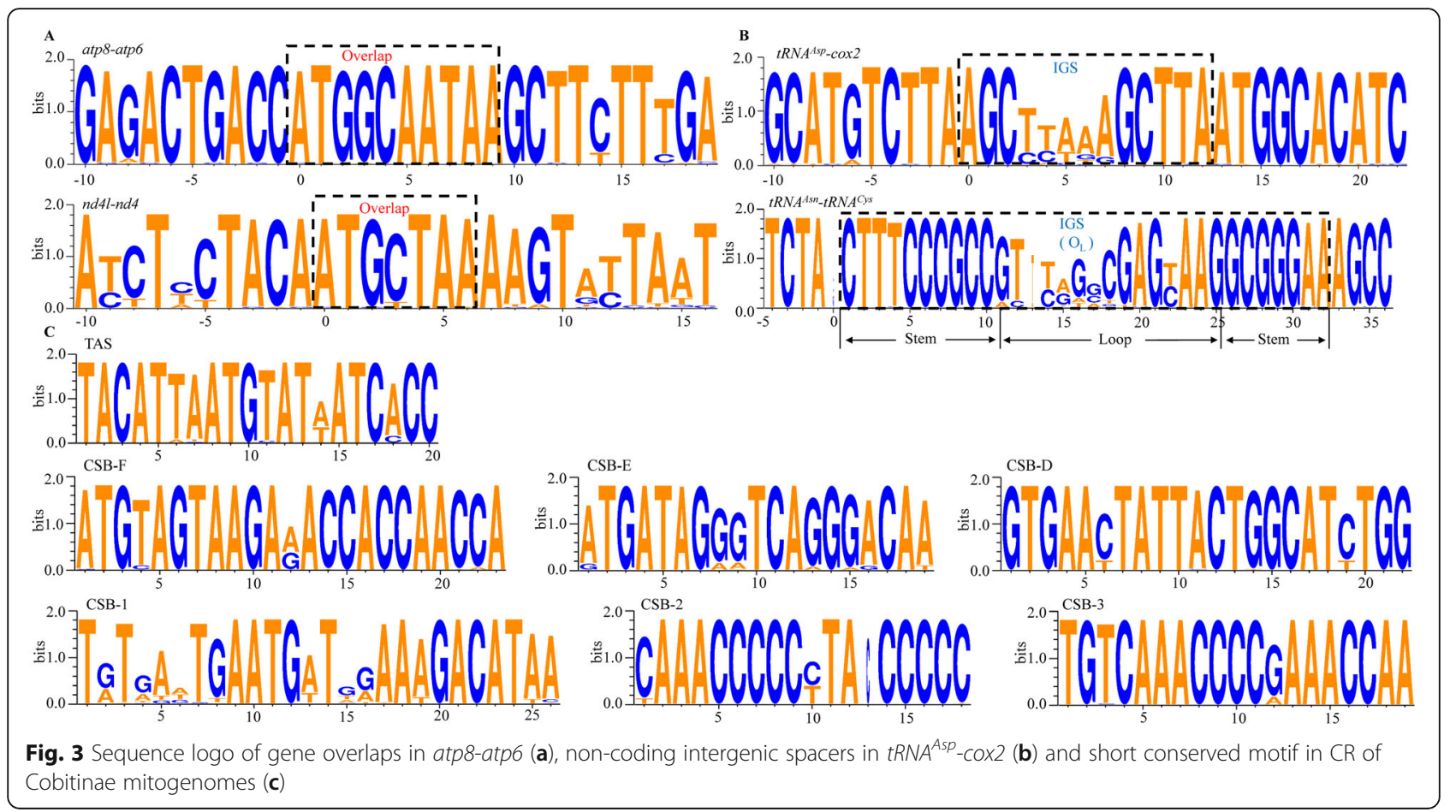

southern lineages, Pangio was estimated to have occurred about 20.14-29.88 Ma, and the divergence times of the four species analyzed in this study are congruent with the previous described dating [24].

\section{Discussion}

In this study, we conducted a comparative mitogenome analysis and revealed the conserved and unique characteristics of 58 Cobitinae mitogenomes. Cobitinae mitogenomes display highly conserved tRNA secondary structure, overlaps and non-coding intergenic spacers. Among the 22 tRNAs, $t R N A^{\operatorname{ser}(A G N)}(S 1)$ is the only one that is not folded into the typical clover-leaf secondary structure (Fig. 2a). Loss of stem in $S 1$ is common character among Cobitinae and other metazoan mitogenomes $[57,58]$. Similarly, the widespread unmatched base pairs among Cobitinae tRNAs is also a conserved feature in the eukaryote mitogenome [59-61]. Although their functions are not clear in fish, the unmatched base pairs are considered as the current state of evolutionary and irreversible process, which might be caused by tRNA editing [62].

Like other cyprinid fishes [14, 63], two long overlaps and two long IGSs were found in Cobitinae mitogenomes. The motif "ATGCTAA" in nd4l-nd4 was conserved in vertebrates, including fish, turtle and human

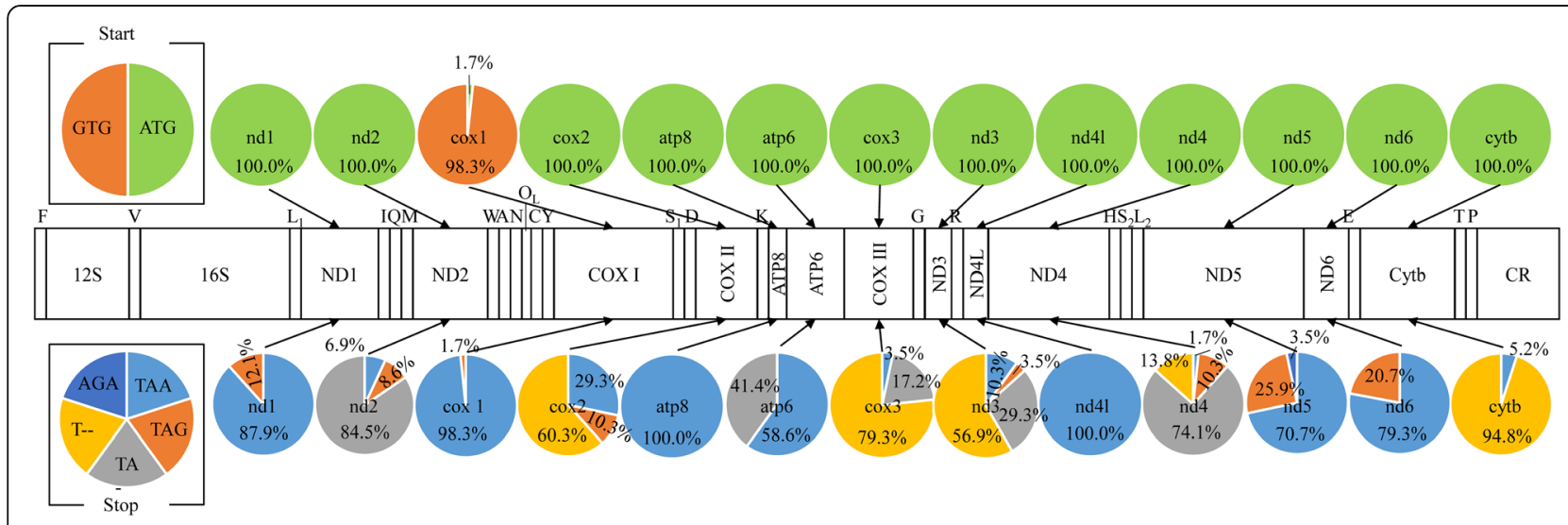

Fig. 4 Usage bias of start and stop codons of 13 PCGs in Cobitinae mitogenomes. Pie graphs show the use frequency of start and stop codons. Gene abbreviations are the same as Table 2 


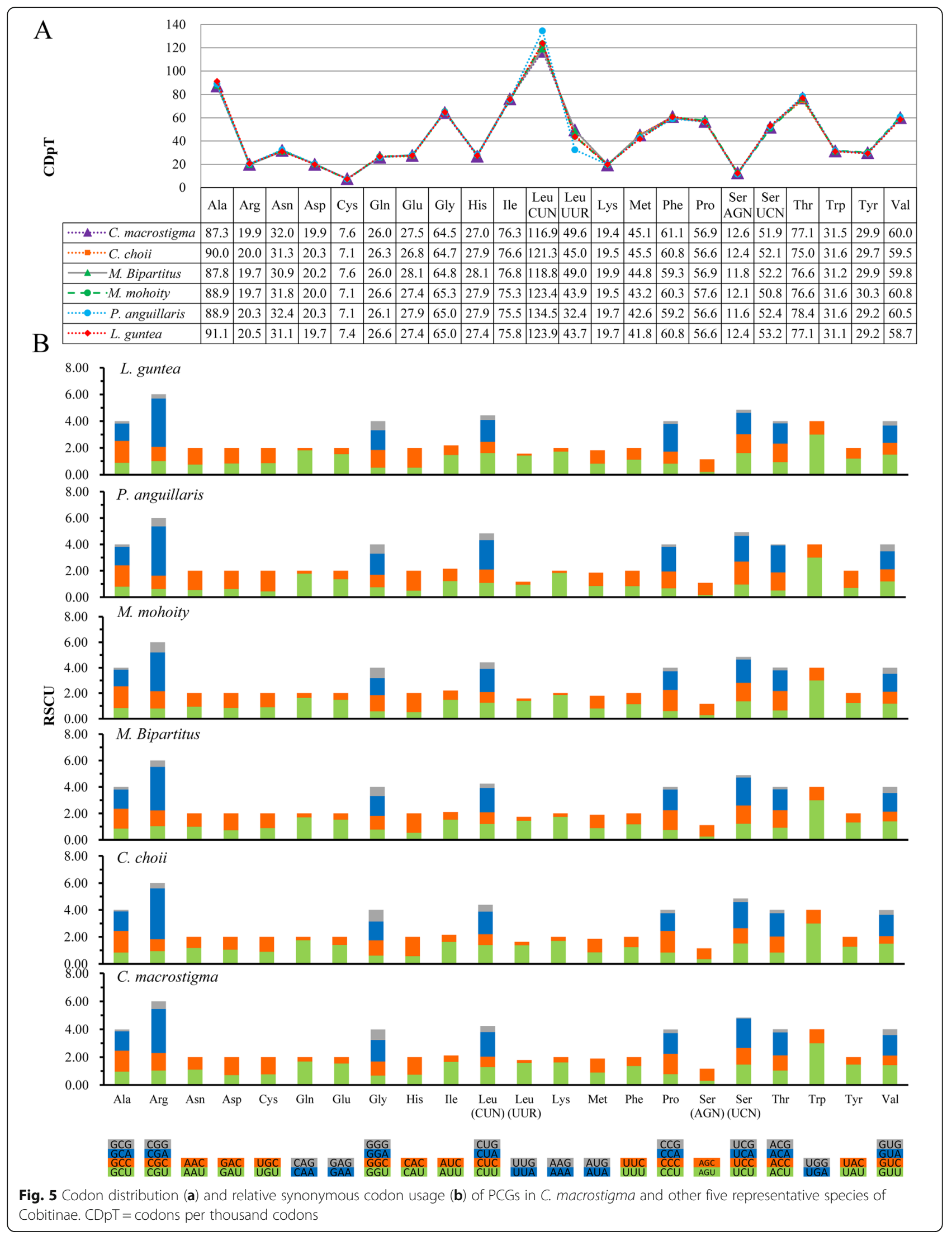




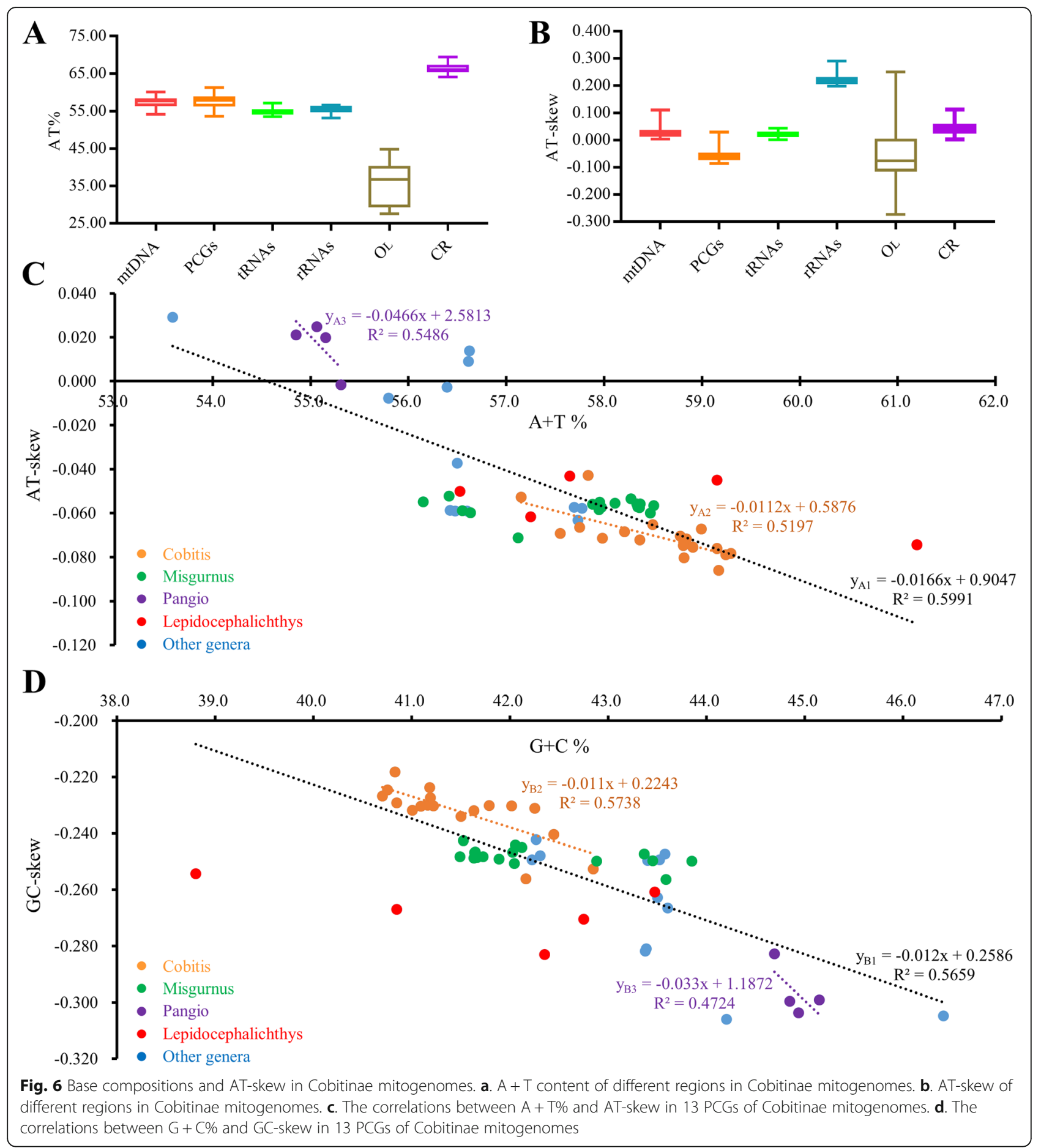

[14, 63-66]. However, in comparison with the conserved motif (ATGATAA) in other Cypriniformes fishes, there is a specific $3 \mathrm{bp}$ insertion (GCA) in the atp8-atp6 overlap motif of Cobitinae and other loaches [67-69], indicating this insertion is a characteristic feature of loaches. IGSs are important for transcription and associated with gene rearrangement in insects [70-72]. It is commonly assumed that IGS had a rapid nucleotide substitution rate under relaxed selection [73]. Moreover, Cobitinae mitogenomes share highly conserved sequences in IGSs that are immediately adjacent to tRNAs, such as "CTTTCCCGCC", "AAGGCGGGA" and "AGC". Whether these conserved sequences have a function or not and how they act awaits further investigation. As the longest IGSs, CR plays an important role in controlling the transcription and replication of mtDNA molecule by 
Table 3 Base composition and skewness of the mitogenomes in C. macrostigma and other five representative species of Cobitinae

\begin{tabular}{|c|c|c|c|c|c|c|c|c|c|c|c|c|c|c|c|c|c|c|c|}
\hline & $\begin{array}{l}\text { Size } \\
\text { (bp) }\end{array}$ & $A \%$ & $\begin{array}{l}\mathrm{T} \\
\text { (U)\% }\end{array}$ & $\mathrm{C} \%$ & G\% & АT\% & GC\% & $\begin{array}{l}\text { AT- } \\
\text { skew }\end{array}$ & $\begin{array}{l}\text { GC- } \\
\text { skew }\end{array}$ & & $\begin{array}{l}\text { Size } \\
\text { (bp) }\end{array}$ & $\mathrm{A} \%$ & $\begin{array}{l}\text { T } \\
\text { (U)\% }\end{array}$ & $\mathrm{C} \%$ & G\% & АT\% & GC\% & $\begin{array}{l}\text { AT- } \\
\text { skew }\end{array}$ & $\begin{array}{l}\text { GC- } \\
\text { skew }\end{array}$ \\
\hline \multicolumn{10}{|c|}{ C. macrostigma } & \multicolumn{10}{|c|}{ Canthophrys gongota } \\
\hline $\begin{array}{l}\text { all } \\
\text { mtDNA }\end{array}$ & 16,636 & 29.5 & 28.8 & 25.1 & 16.6 & 58.3 & 41.7 & 0.013 & -0.205 & $\begin{array}{l}\text { all } \\
\text { mtDNA }\end{array}$ & 16,561 & 31.1 & 25.6 & 27.3 & 16.0 & 56.7 & 43.3 & 0.096 & $-\overline{0.260}$ \\
\hline PCGs & 11,472 & 27.3 & 31.5 & 25.4 & 15.9 & 58.8 & 41.2 & -0.038 & - & PCGS & 11,425 & 28.6 & 28.1 & 27.8 & 15.6 & 56.6 & 43.4 & 0.009 & $-\overline{0.281}$ \\
\hline $\begin{array}{l}\text { 1st of } \\
\text { PCGs }\end{array}$ & 3814 & 26.2 & 23.2 & 24.7 & 25.9 & 49.4 & 50.6 & 0.063 & 0.025 & $\begin{array}{l}\text { 1st of } \\
\text { PCGs }\end{array}$ & 3798 & 29.1 & 20.2 & 27.0 & 23.7 & 49.3 & 50.7 & 0.179 & $\begin{array}{l}- \\
0.064\end{array}$ \\
\hline $\begin{array}{l}\text { 2nd of } \\
\text { PCGs }\end{array}$ & 3814 & 18.2 & 40.9 & 27.3 & 13.6 & 59.1 & 40.9 & -0.385 & -0.335 & $\begin{array}{l}\text { 2nd of } \\
\text { PCGs }\end{array}$ & 3798 & 19.5 & 38.9 & 27.8 & 13.8 & 58.4 & 41.6 & -0.331 & $\begin{array}{l}- \\
0.337\end{array}$ \\
\hline $\begin{array}{l}\text { 3rd of } \\
\text { PCGs }\end{array}$ & 3814 & 37.3 & 30.2 & 24.3 & 8.2 & 67.5 & 32.5 & 0.105 & -0.496 & $\begin{array}{l}\text { 3rd of } \\
\text { PCGs }\end{array}$ & 3798 & 40.9 & 20.9 & 31.4 & 6.8 & 61.8 & 38.2 & 0.323 & -0.644 \\
\hline tRNAs & 1557 & 28.3 & 26.9 & 21.6 & 23.2 & 55.2 & 44.8 & 0.024 & 0.037 & tRNAs & 1558 & 28.6 & 26.2 & 22.3 & 22.9 & 54.8 & 45.2 & 0.044 & 0.014 \\
\hline rRNAs & 2627 & 33.2 & 22.1 & 23.0 & 21.7 & 55.3 & 44.7 & 0.201 & -0.028 & rRNAs & 2628 & 35.0 & 19.3 & 25.0 & 20.7 & 54.3 & 45.7 & 0.290 & -0.095 \\
\hline CR & 917 & 34.4 & 32.0 & 19.4 & 14.3 & 66.3 & 33.7 & 0.036 & -0.152 & $C R$ & 901 & 35.6 & 32.7 & 18.9 & 12.8 & 68.4 & 31.6 & 0.042 & -0.193 \\
\hline \multicolumn{10}{|c|}{ M. bipartitus } & \multicolumn{10}{|c|}{ Paramisgurnus dabryanus (1) } \\
\hline $\begin{array}{l}\text { all } \\
\text { mtDNA }\end{array}$ & 16,636 & 29.8 & 28.0 & 25.9 & 16.4 & 57.7 & 42.3 & 0.032 & -0.226 & $\begin{array}{l}\text { all } \\
\text { mtDNA }\end{array}$ & 16,570 & 29.2 & 27.4 & 26.5 & 17.0 & 56.6 & 43.4 & 0.031 & -0.219 \\
\hline PCGs & 11,471 & 27.4 & 30.6 & 26.3 & 15.8 & 58.0 & 42.0 & -0.055 & -0.251 & PCGs & 11,433 & 26.6 & 29.9 & 27.2 & 16.4 & 56.4 & 43.6 & -0.059 & $\begin{array}{l}- \\
0.247\end{array}$ \\
\hline $\begin{array}{l}\text { 1st of } \\
\text { PCGs }\end{array}$ & 3814 & 26.1 & 22.9 & 24.9 & 26.1 & 49.0 & 51.0 & 0.065 & 0.022 & $\begin{array}{l}\text { 1st of } \\
\text { PCGs }\end{array}$ & 3800 & 26.7 & 21.5 & 26.8 & 25.1 & 48.2 & 51.8 & 0.107 & -0.032 \\
\hline $\begin{array}{l}\text { 2nd of } \\
\text { PCGs }\end{array}$ & 3814 & 18.3 & 40.8 & 27.3 & 13.5 & 59.2 & 40.8 & -0.381 & - & $\begin{array}{l}\text { 2nd of } \\
\text { PCGs }\end{array}$ & 3800 & 19.7 & 39.2 & 27.4 & 13.6 & 58.9 & 41.1 & -0.332 & -0.336 \\
\hline $\begin{array}{l}\text { 3rd of } \\
\text { PCGs }\end{array}$ & 3814 & 37.6 & 27.8 & 26.8 & 7.8 & 65.4 & 34.6 & 0.149 & -0.550 & $\begin{array}{l}\text { 3rd of } \\
\text { PCGs }\end{array}$ & 3800 & 36.2 & 25.7 & 29.7 & 8.4 & 61.9 & 38.1 & 0.170 & -0.557 \\
\hline tRNAs & 1563 & 28.3 & 26.7 & 21.7 & 23.2 & 55.1 & 44.9 & 0.029 & 0.034 & tRNAs & 1559 & 28.3 & 26.5 & 22.1 & 23.1 & 54.8 & 45.2 & 0.033 & 0.021 \\
\hline rRNAs & 2628 & 34.1 & 21.9 & 22.9 & 21.1 & 56.0 & 44.0 & 0.219 & -0.042 & rRNAs & 2631 & 33.8 & 21.2 & 23.7 & 21.3 & 55.0 & 45.0 & 0.229 & -0.052 \\
\hline$C R$ & 916 & 34.3 & 31.2 & 19.9 & 14.6 & 65.5 & 34.5 & 0.047 & -0.152 & $C R$ & 913 & 36.0 & 31.3 & 18.4 & 14.2 & 67.4 & 32.6 & 0.070 & -0.128 \\
\hline \multicolumn{10}{|c|}{ P. anguillaris } & \multicolumn{10}{|l|}{ L. guntea } \\
\hline $\begin{array}{l}\text { all } \\
\text { mtDNA }\end{array}$ & 16,602 & 30.1 & 25.4 & 28.0 & 16.4 & 55.6 & 44.4 & 0.084 & -0.261 & $\begin{array}{l}\text { all } \\
\text { mtDNA }\end{array}$ & 16,566 & 29.3 & 27.8 & 26.7 & 16.2 & 57.1 & 42.9 & 0.026 & -0.244 \\
\hline PCGs & 11,432 & 27.6 & 27.7 & 28.7 & 16.0 & 55.3 & 44.7 & -0.002 & - & PCGs & 11,427 & 26.9 & 30.4 & 27.2 & 15.6 & 57.3 & 42.7 & -0.062 & -0.270 \\
\hline $\begin{array}{l}\text { 1st of } \\
\text { PCGs }\end{array}$ & 3800 & 26.0 & 21.2 & 26.5 & 26.3 & 47.2 & 52.8 & 0.103 & -0.005 & $\begin{array}{l}\text { 1st of } \\
\text { PCGs }\end{array}$ & 3800 & 25.8 & 22.5 & 25.5 & 26.2 & 48.3 & 51.7 & 0.068 & 0.013 \\
\hline $\begin{array}{l}\text { 2nd of } \\
\text { PCGs }\end{array}$ & 3800 & 18.3 & 40.5 & 27.6 & 13.6 & 58.8 & 41.2 & -0.376 & -0.342 & $\begin{array}{l}\text { 2nd of } \\
\text { PCGs }\end{array}$ & 3800 & 18.1 & 40.5 & 27.8 & 13.6 & 58.6 & 41.4 & -0.382 & -0.342 \\
\hline $\begin{array}{l}\text { 3rd of } \\
\text { PCGs }\end{array}$ & 3800 & 38.2 & 21.3 & 32.1 & 8.4 & 59.6 & 40.4 & 0.283 & -0.586 & $\begin{array}{l}\text { 3rd of } \\
\text { PCGs }\end{array}$ & 3800 & 36.5 & 28.1 & 28.4 & 7.1 & 64.6 & 35.4 & 0.131 & -0.602 \\
\hline tRNAs & 1559 & 27.8 & 27.1 & 21.4 & 23.7 & 54.8 & 45.2 & 0.013 & 0.051 & tRNAs & 1559 & 27.6 & 27.5 & 21.3 & 23.6 & 55.1 & 44.9 & 0.001 & 0.051 \\
\hline rRNAs & 2635 & 33.7 & 19.4 & 25.4 & 21.4 & 53.2 & 46.8 & 0.269 & -0.084 & rRNAs & 2623 & 33.6 & 21.5 & 24.1 & 20.8 & 55.1 & 44.9 & 0.221 & -0.075 \\
\hline$C R$ & 928 & 35.0 & 32.0 & 19.7 & 13.3 & 67.0 & 33.0 & 0.045 & -0.196 & $C R$ & 920 & 32.5 & 31.5 & 21.4 & 14.6 & 64.0 & 36.0 & 0.015 & -0.190 \\
\hline
\end{tabular}

several domains and motifs [74, 75]. Although significant length variation were found in CR of vertebrate [76], the three domains can also be recognized in Cobitinae mitogenomes. Furthermore, the AT-skew and GC-skew of CR might reflect the strand asymmetry [77-79]. In teleost, the skew inversion of CR was only found in the mitogenomes of Albula glossodonta and Bathygadus antrode, showing a reversed strand asymmetry [75]. The normal Cobitinae mitogenomes CR skewness indicates that the strand asymmetry is not reversed.

The phylogenetic analyses show the monophyly of the genus Pangio and Lepidocephalichthys, consistent with the previous study [35]. However, Cobitis, the biggest genus of Cobitinae [15], is a complex and controversial 


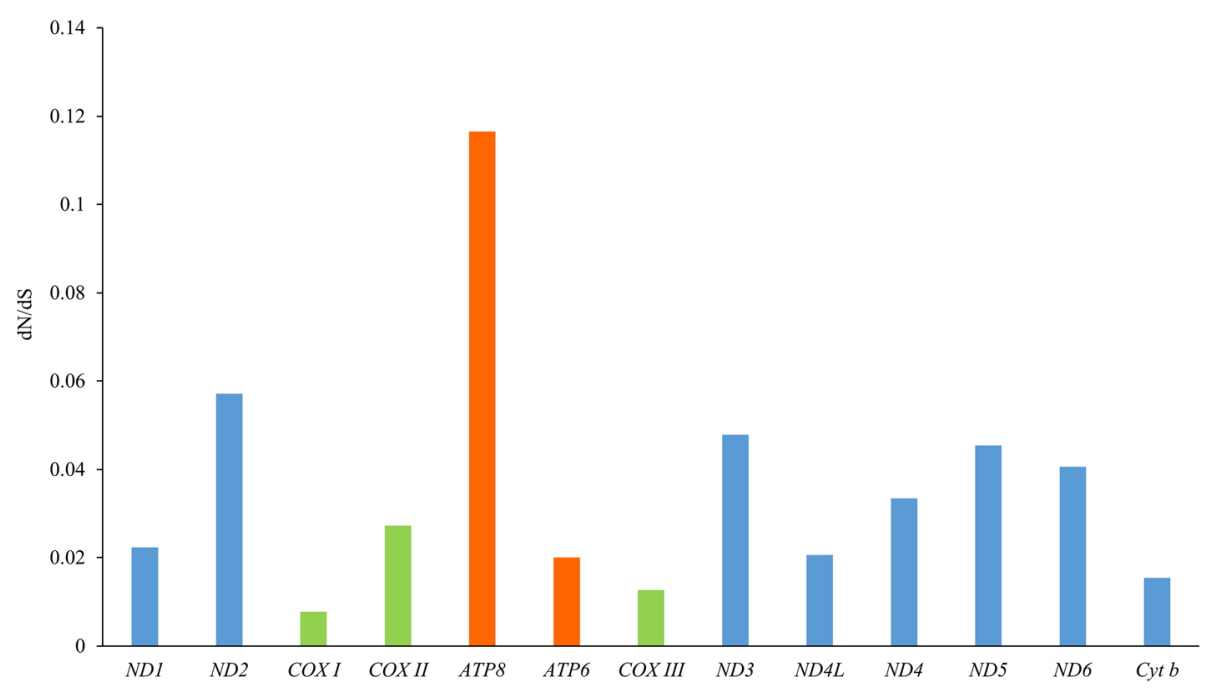

Fig. 7 Nonsynonymous/synonymous ratios $(\omega=\mathrm{dN} / \mathrm{dS})$ of the 13 PCGs of Cobitinae mitogenomes

paraphyletic group. Similar to the trees constructed by cyt $b[25,80,81]$, Iksookimia, Kichulchoia and Niwaella species were nested within Cobitis, implying a close relationship among them. Perdices [37] proposed that these species of Iksookimia, Kichulchoia, and Niwaella might belong to genus Cobitis, as morphologically specialized species derived from a local Cobitis species. However, this assumption awaits more morphological, karyological and molecular investigation. In addition, our phylogenetic analysis confirmed the assumption that $M$. mizolepis and $P$. dabryanus are conspecific $[33,80]$ and the different lineages under the species name $C$. striata and $C$. takatsuensis might actually represent different species.

The species of Misgurnus were separated into two independent clade and clustered into Cobitis species and $P$. dabryanus- $K$. naktongensis, respectively. The same results were observed in the trees based on the cyt $b$ [80] and 13 PCGs from 28 cobitidae species [47]. However, all Misgurnus and Koreocobitis species were grouped into a monophyletic clade when their phylogenetic relationships were constructed by nuclear gene rag-1 [80]. This incongruity between mitochondrial and nuclear gene trees was explained by the different evolutionary rate of markers, hybridization or introgression [82]. It is commonly believed that hybridization and subsequent mtDNA introgression might occur between ancestral species of Cobitis and ancestral species of Misgurnus $[35,80]$. In this study, we collected 14 mitogenomes from $M$. anguillicaudatus, which were divided into two genetically divergent clades. The similar phenomenon has been reported by several previous studies, which is explained by hybridization and mtDNA introgression $[34,35,47,83,84]$. Considering that $M$. anguillicaudatus clustered into the clade of Misgurnus and
Koreocobitis by nuclear analyses [80], we supposed that the 12 mitogenomes (No. 1-12) of $M$. anguillicaudatus in Misgurnus clade A could be considered as the introgressed mtDNA type because of their close relationship with Cobitis species, whereas the other two individuals in Misgurnus clade B retained the original M. anguillicaudatus mitogenomes. $M$. anguillicaudatus with introgressed mtDNA type spread over most of East Asia, including China, Japan and Korea. M. anguillicaudatus shows extensive ploidy variability in nature. Besides most common diploid individuals $(2 n=50)$, triploid $(3 n=75)$ and tetraploid $(4 n=100)$ have been frequently recorded in some localities of China and Japan [21, 47, 85, 86]. Rare pentaploid $(5 n=125)$ and even hexaploid $(6 n=$ 150) individuals were found in the Yangtze River basin [87]. All of $M$. anguillicaudatus polyploids analyzed in this study belonged to the introgressed mtDNA type. Since mtDNA is inherited maternally, these polyploids might have originated from the diploid $M$. anguillicaudatus with introgressed mtDNA. Further analyses are needed to confirm this hypothesis of inter-genus mtDNA introgression based on a large-scale sampling with quantitative morphological features, definite ploidy, and more genes from both mitochondria and nuclear genomes.

The first split of Cobitinae lineages was estimated to have occurred in the late Eocene (42.11 Ma, 95\% HPD: 36.35-47.86 Ma), separating northern clade and southern lineages, consistent with reconstruction dates of the paleo-drainages of East Asia [35, 88]. Cobitinae fishes in Clade I and Clade II, nominated as "northern clade" and "southern lineages" respectively, show a distinct disjunctive distribution with a small area of sympatry in Vietnam [35]. Consistent with their locations, the northern clade 


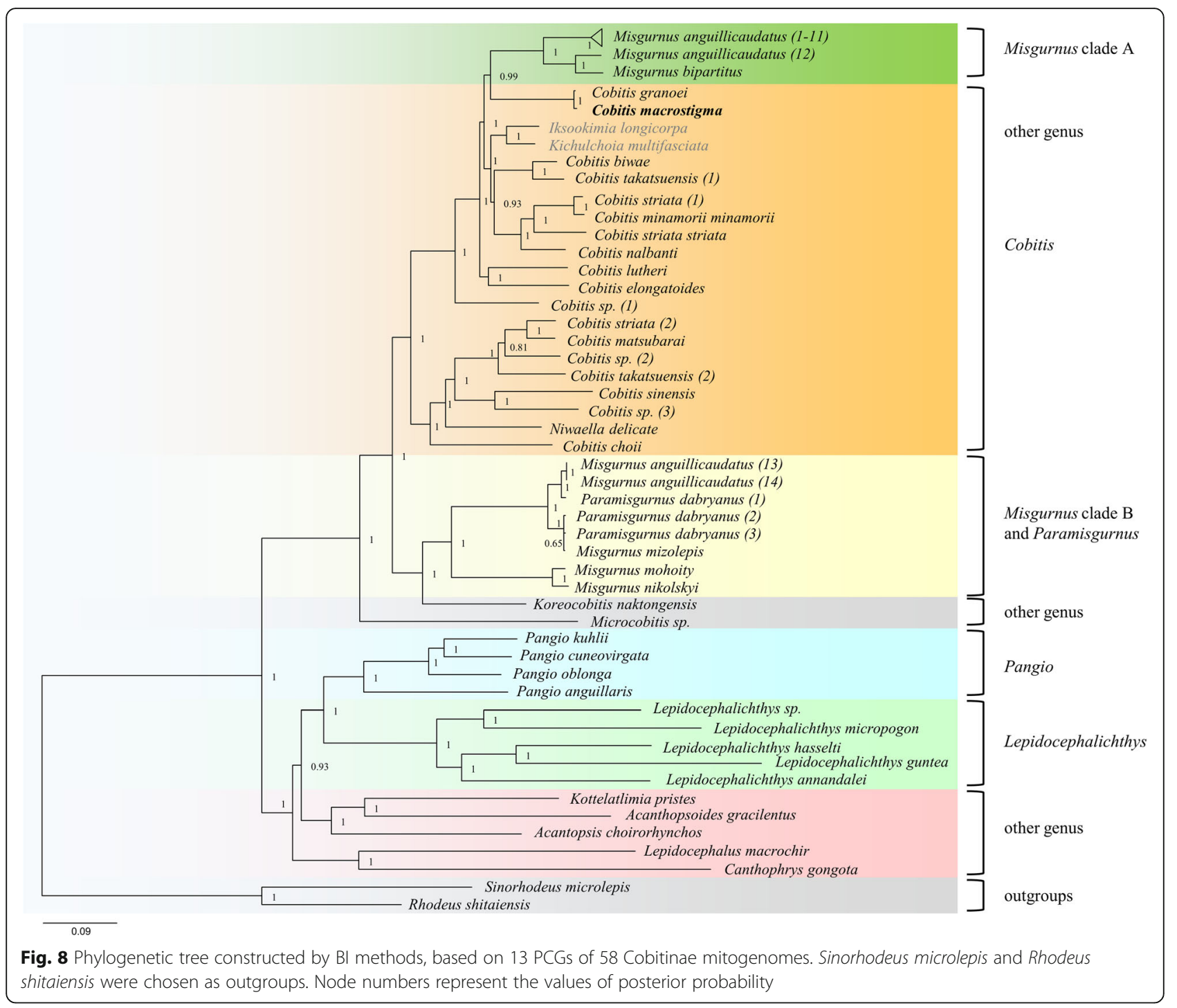

spread to most of East Asia, Siberia and Europe, while the southern lineages distribute across the Indian subcontinent and Southeast Asia after their isolation. The nodes within northern clade and southern lineage appear asynchronous, implying that some local dominant factors, rather than large-scale events, might shape the evolution within northern or southern lineage.

\section{Conclusions}

This study represents the first comparative mitogenome and phylogenetic analyses within Cobitinae. The conserved and unique characteristics of 58 Cobitinae mitogenomes were revealed. We observed distinct base compositions among different genus and identified a specific 3 bp insertion (GCA) in the atp8-atp6 overlap as a unique feature of loaches. ML and BI analyses both strongly support the paraphyly of Cobitis and polyphyly of Misgurnus. In addtion, Cobitinae might have split into northern and southern lineages in the late Eocene (42.11 Ma), and a mtDNA introgression between Cobitis and Misgurnus might have occured about $14.40 \mathrm{Ma}$. The current study provides new insights into the mitogenome features and evolution of Cobitinae fishes.

\section{Methods}

\section{Sampling, sequencing and assembly}

The C. macrostigma analyzed in this study was caught from the Yangtze River in Yibin City, Sichuan Province, China (N: 28 $46^{\prime} 6.01^{\prime \prime}$, E: $104^{\circ} 38^{\prime} 13.99^{\prime \prime}$ ) in October 2018 and five individual were transported to the laboratory (National Aquatic Biological Resource Center, NABRC) in oxygen-rich water. It possesses 5-9 large and round spot in the midline of lateral body side [89] (Fig. 1). Before sampling, they were reared in a square 


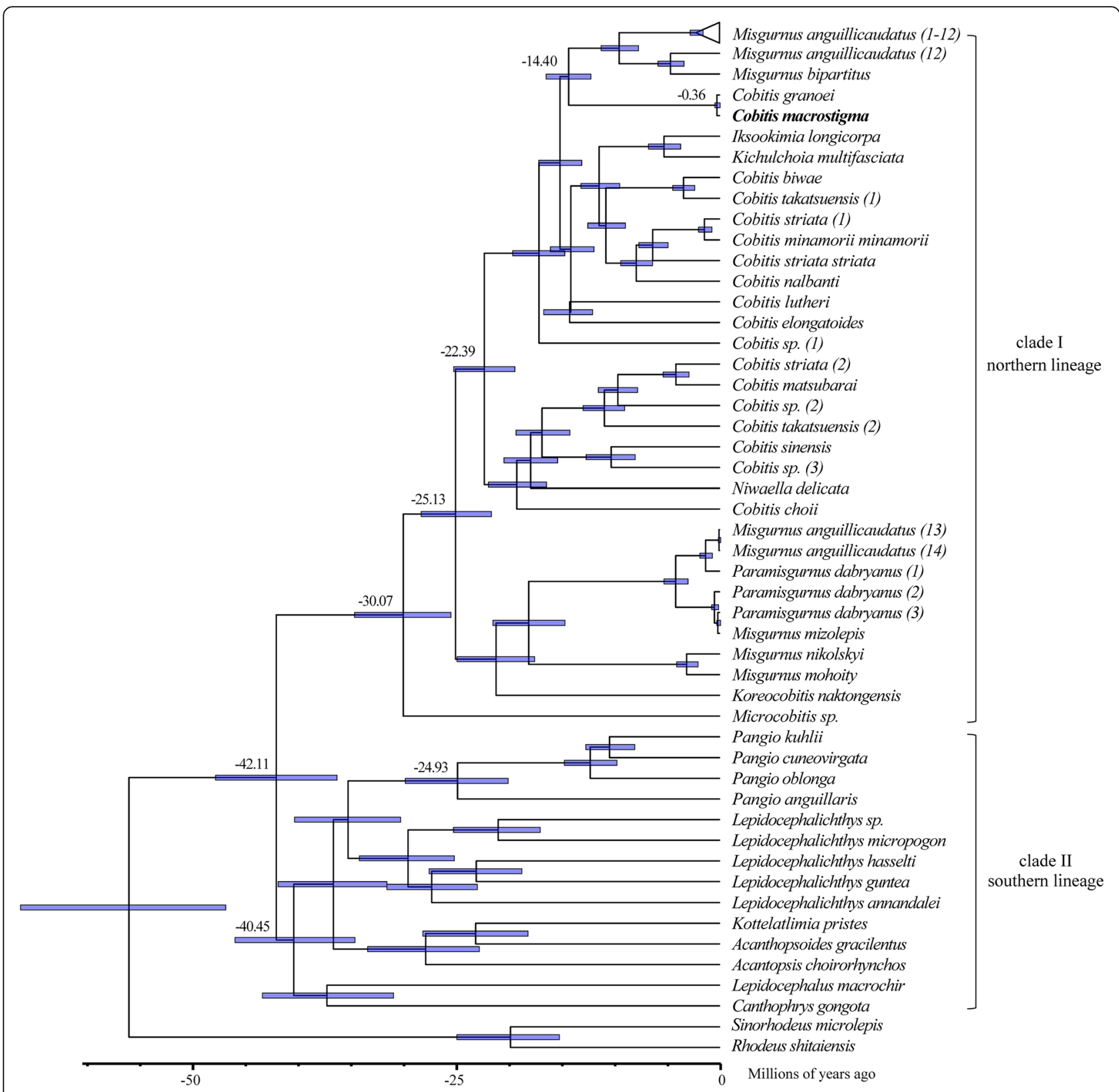

Fig. 9 The divergence times of Cobitinae fishes. The ranges of 95\% HPD intervals are represented by the blue bars

and glass recirculating freshwater tanks with a volume of about $100 \mathrm{~L}$, at $22^{\circ} \mathrm{C}$ on a $14 \mathrm{~h}$ (hour) light $/ 10 \mathrm{~h}$ dark cycle for morphological identification. After deep and overdosed anesthesia with styrylpyridine (a common anaesthetic used in fish, $30-50 \mathrm{mg} / \mathrm{L}$; aladdin, China), one healthy one-year-old female fish, $7 \mathrm{~cm}$ in length and 1.8 $\mathrm{g}$ in weight, was euthanized by immediately cutting off the spinal cord adjacent to the head. Total DNA was extracted according to the Ezup Column Animal Genomic DNA Kit technical manual (Sangon, Shanghai, China). PCR primers were designed based on the conserved sequences between the mitogenomes of $C$. granoei (GenBank: NC_023473.1) and C. sinensis (GenBank: NC_ 007229.1). 742-2495 bp DNA were amplified by using High Fidelity DNA Polymerase (Yeasen, Shanghai) (Supplementary Table 1). To obtain accurate sequences, we chose a cloning strategy. According to manual, PCR amplicon was purified, ligated ESI-Blunt vector (Yeasen, Shanghai) and transfected into $5 \alpha$ Chemically Competent Cell (Tsingke Biological Technology, Beijing). The positive clones were sequenced by Quintara Biosciences (Wuhan, China). The segments, longer than $1500 \mathrm{bp}$, 
were sequenced using the primer walking sequencing strategy. The resulting DNA sequences were assembled using DNAStar (DNASTAR Inc., USA) [90]. Other 57 Cobitinae mitogenomes were download from NCBI GenBank database [38-55].

\section{Gene annotation and bioinformatic analyses}

tRNA genes and their secondary structures were predicted with MITOS [91] and tRNAscan-SE 2.0 with default parameters [92]. All 13 PCGs and two rRNA genes were annotated by comparison with the sequences of other Cobitinae fishes in GenBank (https://blast.ncbi. nlm.nih.gov/). The mtDNA maps were drawn using CGView Server V1.0 [93]. The sequence logos of gene overlaps and non-coding IGSs were drawn using WebLogo 3.7.4 [94]. The base composition, codon distributions and relative synonymous codons usage were calculated using DNAStar (DNASTAR Inc., USA) [90], MEGA 7.0 [95] and Microsoft Excel 2010. Skewness was measured using the formulas: AT-skew $=(\mathrm{A} \%-\mathrm{T} \%) /$ $(\mathrm{A} \%+\mathrm{T} \%)$ and $\mathrm{GC}$-skew $=(\mathrm{G} \%-\mathrm{C} \%) /(\mathrm{G} \%+\mathrm{C} \%)[79]$. The silimlarity of the sequences was calculated in MEGA 7.0 [95] under p-distance and NCBI-BLAST (https://blast.ncbi.nlm.nih.gov/Blast.cgi).

\section{Phylogenetic analyses}

The phylogenetic analysis was performed based on 13 PCGs of 58 Cobitinae mitogenomes. Sinorhodeus microlepis and Rhodeus shitaiensis were chosen as the outgroups (Table 1). Each of the 13 gene sequences was separately aligned using Muscle v3.8.31 [96] and concatenated into a sequence matrix by PhyloSuite v1.2.2 [97]. Then PartitionFinder2 [98] was used to find the best partitioning strategy and to calculate the best-fit evolutionary models for each subset. For the alignment, a scheme with eight partitions was selected and GTR + $\mathrm{G}+\mathrm{I}$ was chosen as the best-fit evolutionary model for each partition. Phylogenetic trees were constructed by the maximum likelihood (ML) method and bayesian inference (BI). The ML method was implemented in RAxML v8.2.12 [99]. Each partition scheme was run with the GTRGAMMAI model, and 1000 rapid bootstrapping replications were set to evaluate the bootstrap support values and search for the best-scoring ML tree. The BI phylogeny was performed in MrBayes v3.1.2 [100] with the "unlink" and "prest ratepr = variable" model parameters. 10,000,000 generations were run in two independent runs of four independent Markov Chain Monte Carlo (MCMC) chains, and were sampled every 1000 generations. The convergence of the BI analyses was investigated using Tracer v1.7.1 software. The first 2500 trees were discarded as conservative burn-in, and the rests were used to generate a majority rule consensus tree.
In cobitid fishes, $0.680 \%$ (divergence per pairwise comparison per $\mathrm{Ma}$ ) was calculated and suggested for the mutation rates of $c y t b$ gene [32]. In this study, BEAST v1.10.4 [101] was used to estimate the divergence time with the rate $(0.68 \%)$. GTR + G+I was chosen as the best fit model by PartitionFinder2 [98]. The best-fit clock type and tree prior were selected from two clock models (strict clock and uncorrelated relaxed clock) and four tree priors (Yule process, Exponential growth, Constant size and Bayesian skyline) by comparing the marginal likelihood values estimated by path sampling [102]. The analyses were simultaneously run for 20,000,000 generations, with parameters sampled every 1000, then the first $25 \%$ of the trees were discarded as burn-in. Tracer v1.5 [103] and Figtree were used to assess the convergence and view trees, respectively.

\section{Supplementary Information}

The online version contains supplementary material available at https://doi. org/10.1186/s12864-020-07360-w. Additional file 1: Table S1. List of primers used to amplify the
mitogenome of C. macrostigma.

Additional file 2: Table S2. Length, base composition and skewness of Cobitinae fish mitogenomes.

Additional file 3: Table S3. Start and stop codons of 13 PCGs in Cobitinae mitogenomes.

Additional file 4: Table S4. Marginal likelihood values of different combinations of clock model and tree prior.

Additional file 5: Figure S1. Codon distribution $(\mathbf{A})$ and relative synonymous codon usage (B) of PCGs in the 58 Cobitinae mitogenomes. $\mathrm{CDpT}=$ codons per thousand codons.

Additional file 6: Figure S2. Phylogenetic tree constructed by ML methods, based on 13 PCGs of 58 Cobitinae mitogenomes. Sinorhodeus microlepis and Rhodeus shitaiensis were chosen as outgroups. Node numbers represent the bootstrap value.

\section{Abbreviations}

mitogenome: Mitochondrial genome; mtDNA: Mitochondrial DNA; Ma: Million years ago; tRNA: Transfer RNA; PCG: Protein coding gene; rRNA: Ribosomal RNA; $\mathrm{O}_{\mathrm{L}}$ : Origin of $\mathrm{L}$-strand replication; $\mathrm{CR}$ : Control region; cytb: Cytochrome b; rag-1: Recombination activating gene 1; bp: Base pair; nd1-6: NADH dehydrogenase subunit 1-6; nd4l: NADH dehydrogenase subunit 4 L; cox1-3: Cytochrome oxidase subunit I-III; atp6: ATPase subunit 6; atp8: ATPase subunit 8; DHU: Dihydrouracil; IGS: Non-coding intergenic spacer; RSCU: Relative synonymous codon usage; $\omega$ or dN/dS: Nonsynonymous and synonymous substitutions; HPD: Highest posterior density; ML: Maximum likelihood; Bl: Bayesian inference

\section{Acknowledgments}

The research was supported by the Wuhan Branch, Supercomputing Centre, Chinese Academy of Sciences, China.

\section{Authors' contributions}

$P Y$ and $L Z$ conceived and designed the study. $P Y, Y W, W T Y, L M, Z L$ and $X J Z$ collected the samples and analyzed the data. $P Y$ and $L Z$ wrote the draft manuscript, $Y$ W and JF G revised the manuscript. All authors have read and approved the final manuscript.

\section{Funding}

This work was supported by the Strategic Priority Research Program of the Chinese Academy of Sciences (XDB31000000) and the China Agriculture Research System (CARS-45-07). 


\section{Availability of data and materials}

C. macrostigma mitochondrial genome has been deposited in GenBank under the accession numbers MT259034. The 59 mitogenomes from Cobitinae species, Sinorhodeus microlepis and Rhodeus shitaiensis were downloaded from GenBank. Their accession numbers and references were listed in Table 1. Other supporting results are included within the article and its additional files.

\section{Ethics approval and consent to participate}

The C. macrostigma analyzed in this study was caught from the Yangtze River in Yibin City, Sichuan Province, China and reared in the National Aquatic Biological Resource Center (NABRC). The acquisition of experimental fish complies with the laws of Fishery Administration of the Ministry of Agriculture and Rural Affairs of the People's Republic of China. We confirm that C. macrostigma is not an endangered or protected species (http://www. iucnredlist.org). The protocol, including the research.

question, key design features, and analysis plan, was provided to the Animal Care and Use Committee of Institute of Hydrobiology, Chinese Academy of Sciences before the study, and all procedures in this research performed with the approval of the Committee. No ethics approval was required for the public sequence data used in this study.

\section{Consent for publication}

Not applicable.

\section{Competing interests}

The authors declare no competing interests.

\section{Author details}

'State Key Laboratory of Freshwater Ecology and Biotechnology, Institute of Hydrobiology, the Innovation Academy of Seed Design, Chinese Academy of Sciences, Wuhan 430072, China. 'University of Chinese Academy of Sciences, Beijing 100049, China.

Received: 28 May 2020 Accepted: 29 December 2020 Published online: 14 January 2021

\section{References}

1. Satoh TP, Miya M, Mabuchi K, Nishida M. Structure and variation of the mitochondrial genome of fishes. BMC Genomics. 2016;17:719.

2. Cuppari A, Fernandez-Millan P, Battistini F, Tarres-Sole A, Lyonnais S, Iruela $G$, et al. DNA specificities modulate the binding of human transcription factor a to mitochondrial DNA control region. Nucleic Acids Res. 2019; 47(12):6519-37.

3. Shadel GS, Clayton DA. Mitochondrial DNA maintenance in vertebrates. Annu Rev Biochem. 1997;66:409-35.

4. Lin CP, Danforth BN. How do insect nuclear and mitochondrial gene substitution patterns differ? Insights from Bayesian analyses of combined datasets. Mol Phylogenet Evol. 2004;30(3):686-702.

5. Elson JL, Lightowlers RN. Mitochondrial DNA clonality in the dock: can surveillance swing the case? Trends Genet. 2006;22(11):603-7.

6. Curole JP, Kocher TD. Mitogenomics: digging deeper with complete mitochondrial genomes. Trends Ecol Evol. 1999;14(10):394-8.

7. Cole TL, Ksepka DT, Mitchell KJ, Tennyson AJD, Thomas DB, Pan HL, et al. Mitogenomes uncover extinct penguin taxa and Reveal Island formation as a key driver of speciation. Mol Biol Evol. 2019;36(4):784-97.

8. Baron S, van der Merwe NA, Maritz-Olivier C. The genetic relationship between R. microplus and R. decoloratus ticks in South Africa and their population structure. Mol Phylogenet Evol. 2018;129:60-9.

9. Min-Shan Ko A, Zhang Y, Yang MA, Hu Y, Cao P, Feng X, et al. Mitochondrial genome of a 22,000-year-old giant panda from southern China reveals a new panda lineage. Curr Biol. 2018;28(12):R693-4.

10. Wei M, Yu P, Yang Y, Wan Q. The complete mitochondrial genome of Leptobotia taeniaps (Cypriniformes: Cobitidae). Mitochondrial DNA part a, DNA mapping, sequencing, and analysis. Mitochondrial DNA A DNA Mapp Seq Anal. 2016;27(3):1707-8.

11. Luo H, Kong $X$, Chen $S$, Shi W. Mechanisms of gene rearrangement in 13 bothids based on comparison with a newly completed mitogenome of the threespot flounder, Grammatobothus polyophthalmus (Pleuronectiformes: Bothidae). BMC Genomics. 2019;20(1):792.
12. Dong S, Zhao C, Zhang S, Zhang L, Wu H, Liu H, et al. Mitochondrial genomes of the early land plant lineage liverworts (Marchantiophyta): conserved genome structure, and ongoing low frequency recombination. BMC Genomics. 2019;20(1):953.

13. Ponts N, Gautier C, Gouzy J, Pinson-Gadais L, Foulongne-Oriol M, Ducos C, et al. Evolution of Fusarium tricinctum and Fusarium avenaceum mitochondrial genomes is driven by mobility of introns and of a new type of palindromic microsatellite repeats. BMC Genomics. 2020;21(1):358.

14. Yu P, Zhou L, Zhou XY, Yang WT, Zhang J, Zhang XJ, et al. Unusual AT-skew of Sinorhodeus microlepis mitogenome provides new insights into mitogenome features and phylogenetic implications of bitterling fishes. Int J Biol Macromol. 2019;129:339-50.

15. Froese R, Pauly D. FishBase. World wide web electronic publication. Wwwfishbaseorg; 2019. version 04.

16. Gao J, Koshio S, Nguyen BT, Wang WM, Cao XJ. Comparative studies on lipid profiles and amino acid composition of wild and cultured dojo loach Misgurnus anguillicaudatus obtained from southern Japan. Fish Sci. 2012; 78(6):1331-6.

17. Chen J, Chen L. Effects of chitosan-supplemented diets on the growth performance, nonspecific immunity and health of loach fish (Misgurnus anguillicadatus). Carbohydr Polym. 2019;225:115227.

18. Gao Y, He J, He Z, Li Z, Zhao B, Mu Y, et al. Effects of fulvic acid on growth performance and intestinal health of juvenile loach Paramisgurnus dabryanus (Sauvage). Fish Shellfish Immunol. 2017;62:47-56.

19. Juchno D, Jablonska O, Boron A, Kujawa R, Leska A, Grabowska A, et al. Ploidy-dependent survival of progeny arising from crosses between natural allotriploid Cobitis females and diploid C-taenia males (Pisces, Cobitidae). Genetica. 2014;142(4):351-9.

20. Morishima K, Yoshikawa H, Arai K. Diploid clone produces unreduced diploid gametes but tetraploid clone generates reduced diploid gametes in the Misgurnus loach. Biol Reprod. 2012;86(2):33.

21. Zhou L, Gui J. Natural and artificial polyploids in aquaculture. Aquaculture Fish. 2017;2(3):103-11.

22. Janko K, Culling MA, Rab P, Kotlik P. Ice age cloning--comparison of the quaternary evolutionary histories of sexual and clonal forms of spiny loaches (Cobitis; Teleostei) using the analysis of mitochondrial DNA variation. Mol Ecol. 2005;14(10):2991-3004.

23. Janko K, Bohlen J, Lamatsch D, Flajshans M, Epplen JT, Rab P, et al. The gynogenetic reproduction of diploid and triploid hybrid spined loaches (Cobitis: Teleostei), and their ability to establish successful clonal lineages-on the evolution of polyploidy in asexual vertebrates. Genetica. 2007;131(2): 185-94.

24. Bohlen J, Šlechtová V, Tan HH, Britz R. Phylogeny of the southeast Asian freshwater fish genus Pangio (Cypriniformes; Cobitidae). Mol Phylogenet Evol. 2011;61(3):854-65.

25. Chen YX, Chen YF. Three new species of cobitid fish (Teleostei, Cobitidae) from the river Xinjiang and the river Le'anjiang, tributaries of Lake Poyang of China, with remarks on their classification. Folia Zool. 2013;62(2):83-95.

26. Peng G, Zhu B, Yang D, Su L, Shi H, Li D. Microplastics in sediments of the Changjiang estuary, China. Environ Pollut. 2017;225:283-90.

27. Wang J, Wang M, Ru S, Liu X. High levels of microplastic pollution in the sediments and benthic organisms of the South Yellow Sea, China. Sci Total Environ. 2019;651(Pt 2):1661-9.

28. Buj I, Caleta M, Marcic Z, Sanda R, Vukic J, Mrakovcic M. Different histories, different DestiniesImpact of evolutionary history and population genetic structure on extinction risk of the Adriatic Spined loaches (genus Cobitis; Cypriniformes, Actinopterygii). PLoS One. 2015;10(7):e0131580.

29. Zhao S, Feng C, Quan W, Chen X, Niu J, Shen Z. Role of living environments in the accumulation characteristics of heavy metals in fishes and crabs in the Yangtze River estuary, China. Mar Pollut Bull. 2012;64(6):1163-71.

30. Allert AL, Fairchild JF, Schmitt CJ, Besser JM, Brumbaugh WG, Olson SJ. Effects of mining-derived metals on riffle-dwelling benthic fishes in Southeast Missouri, USA. Ecotoxicol Environ Saf. 2009;72(6):1642-51.

31. Perdices A, Bohlen J, Doadrio I. The molecular diversity of adriatic spined loaches (Teleostei, Cobitidae). Mol Phylogenet Evol. 2008;46(1):382-90.

32. Doadrio I, Perdices A. Phylogenetic relationships among the Ibero-African cobitids (Cobitis, cobitidae) based on cytochrome b sequence data. Mol Phylogenet Evol. 2005;37(2):484-93.

33. Slechtova V, Bohlen J, Tan HH. Families of Cobitoidea (Teleostei; Cypriniformes) as revealed from nuclear genetic data and the position of 
the mysterious genera Barbucca, Psilorhynchus, Serpenticobitis and Vaillantella. Mol Phylogenet Evol. 2007:44(3):1358-65.

34. Morishima K, Nakamura-Shiokawa Y, Bando E, Li YJ, Boron A, Khan MM, et al. Cryptic clonal lineages and genetic diversity in the loach Misgurnus anguillicaudatus (Teleostei: Cobitidae) inferred from nuclear and mitochondrial DNA analyses. Genetica. 2008;132(2):159-71.

35. Slechtova $V$, Bohlen J, Perdices A. Molecular phylogeny of the freshwater fish family Cobitidae (Cypriniformes: Teleostei): delimitation of genera, mitochondrial introgression and evolution of sexual dimorphism. Mol Phylogenet Evol. 2008;47(2):812-31.

36. Tang QY, Shi LX, Liu F, Yu D, Liu HZ. Evolution and phylogenetic application of the MC1R gene in the Cobitoidea (Teleostei: Cypriniformes). Zool Res. 2016;37(5):281-9.

37. Perdices A, Bohlen J, Slechtova V, Doadrio I. Molecular evidence for multiple origins of the European Spined loaches (Teleostei, Cobitidae). PLoS One. 2016;11(1):e0144628

38. Saitoh K, Sado T, Mayden RL, Hanzawa N, Nakamura K, Nishida M, et al. Mitogenomic evolution and interrelationships of the Cypriniformes (Actinopterygii: Ostariophysi): the first evidence toward resolution of higherlevel relationships of the world's largest freshwater fish clade based on 59 whole mitogenome sequences. J Mol Evol. 2006;63(6):826-41.

39. Miya M, Sato Y, Fukunaga T, Sado T, Poulsen JY, Sato K, et al. MiFish, a set of universal PCR primers for metabarcoding environmental DNA from fishes: detection of more than 230 subtropical marine species. R Soc Open Sci. 2015;2(7):150088.

40. Kim KY, Lee SY, Bang IC, Nam YK. Complete mitogenome sequence of an endangered freshwater fish, Iksookimia choii (Teleostei; Cypriniformes; Cobitidae). Mitochondrial DNA. 2008;19(5):438-45.

41. Huang S, Tomljanovic T, Tian X, Wang Y, Cao X. The complete mitochondrial genome of natural Cobitis elongatoides (Cypriniformes: Cobitidae). Mitochondrial DNA part a, DNA mapping, sequencing, and analysis. Mitochondrial DNA A DNA Mapp Seq Anal. 2016;27(1):189-90.

42. Song JR, You P. The complete mitochondrial genome of Cobitis granoei (Cyprinformes: Cobitidae). Mitochondrial DNA part a, DNA mapping, sequencing, and analysis. Mitochondrial DNA A DNA Mapp Seq Anal. 2016; 27(1):60-1.

43. Park HK, Kim KS, Kim KY, Bang IC. The full-length mitochondrial genome of Cobitis nalbanti (Teleostei: Cypriniformes: Cobitidae). Mitochondrial DNA Part B-Resources. 2018;3(2):872-3.

44. Saitoh K, Chen WJ, Mayden RL. Extensive hybridization and tetrapolyploidy in spined loach fish. Mol Phylogenet Evol. 2010;56(3):1001-10.

45. Saitoh K, Miya M, Inoue JG, Ishiguro NB, Nishida M. Mitochondrial genomics of ostariophysan fishes: perspectives on phylogeny and biogeography. J Mol Evol. 2003:56(4):464-72.

46. Yu YY, Li YH, Li RW, Wang WM, Zhou XY. Mitochondrial genome of the natural tetraploid loach Misgurnus anguillicaudatus. Mitochondrial DNA. 2014;25(2):115-6.

47. Zhou X, Yu Y, Li Y, Wu J, Zhang X, Guo X, et al. Comparative analysis of mitochondrial genomes in distinct nuclear ploidy loach Misgurnus anguillicaudatus and its implications for polyploidy evolution. PLoS One. 2014;9(3):e92033.

48. Yu YY, Li YH, Li RW, Wang WM, Zhou XY. Complete mitochondrial genome of the natural hexaploid loach, Misgurnus anguillicaudatus (Teleostei: Cypriniformes: Cobitididae). Mitochondrial DNA. 2014;25(2):100-1.

49. Zhang $X$, Wang W, Huang S, Chen G, Bai X, Cao X. The complete mitochondrial genomes of natural diploid and tetraploid loaches Misgurnus anguillicaudatus (Cypriniformes: Cobitidae). Mitochondrial DNA. 2014;25(3): 196-7.

50. Zeng L, Wang J, Sheng J, Gu Q, Hong Y. Molecular characteristics of mitochondrial DNA and phylogenetic analysis of the loach (Misgurnus anguillicaudatus) from the Poyang Lake. Mitochondrial DNA. 2012;23(3):187-200.

51. He S, Gu X, Mayden RL, Chen WJ, Conway KW, Chen Y. Phylogenetic position of the enigmatic genus Psilorhynchus (Ostariophysi: Cypriniformes): evidence from the mitochondrial genome. Mol Phylogenet Evol. 2008;47(1): 419-25.

52. Huang S, Tian X, Wang W, Song W, Zhang X, Bai X, et al. The complete mitochondrial genome of natural Misgurnus bipartitus (Cypriniformes: Cobitidae). Mitochondrial DNA. 2015;26(5):680-1.

53. Yu YY, Song W, Wang YZ, Wang WM, Zhou XY. Complete mitochondrial genome of the Amur weatherfish, Misqurnus mohoity (Teleostei: Cypriniformes: Cobitididae). Mitochondrial DNA. 2015;26(2):310-2.
54. Zhu M, Liu F. Mitochondrial genome sequence of Paramisgurnus dabryanus from the Yellow River estuary: implication for Cobitidae phylogeny. Mitochondrial DNA part a, DNA mapping, sequencing, and analysis. Mitochondrial DNA A DNA Mapp Seq Anal. 2016;27(4):3039-40.

55. Li F, Shao KT, Lin YS, Chang CH. The complete mitochondrial genome of the Rhodeus shitaiensis (Teleostei, Cypriniformes, Acheilognathidae). Mitochondrial DNA. 2015;26(2):301-2.

56. Castellana S, Vicario S, Saccone C. Evolutionary patterns of the mitochondrial genome in Metazoa: exploring the role of mutation and selection in mitochondrial protein coding genes. Genome Biol Evol. 2011;3:1067-79.

57. Zhao Q, Wang J, Wang MQ, Cai B, Zhang HF, Wei JF. Complete mitochondrial genome of dinorhynchus dybowskyi (hemiptera: pentatomidae: asopinae) and phylogenetic analysis of pentatomomorpha species. J Insect Sci. 2018;18(2):1.

58. Lavrov DV, Brown WM. Trichinella spiralis mtDNA: a nematode mitochondrial genome that encodes a putative ATP8 and normally structured tRNAS and has a gene arrangement relatable to those of coelomate metazoans. Genetics. 2001;157(2):621-37.

59. Smith BA, Jackman JE. Saccharomyces cerevisiae Thg 1 uses 5'-pyrophosphate removal to control addition of nucleotides to tRNA (his). Biochemistry-Us. 2014;53(8):1380-91.

60. Betat $\mathrm{H}$, Long $\mathrm{Y}$, Jackman JE, Morl M. From end to end: tRNA editing at 5'and 3'-terminal positions. Int J Mol Sci. 2014;15(12):23975-98.

61. Gray MW. Evolutionary origin of RNA editing. Biochemistry-Us. 2012;51(26): 5235-42.

62. Lavrov DV, Brown WM, Boore JL. A novel type of RNA editing occurs in the mitochondrial tRNAs of the centipede Lithobius forficatus. Proc Natl Acad Sci U S A. 2000;97(25):13738-42.

63. Broughton RE, Milam JE, Roe BA. The complete sequence of the zebrafish (Danio rerio) mitochondrial genome and evolutionary patterns in vertebrate mitochondrial DNA. Genome Res. 2001;11(11):1958-67.

64. Yu P, Ding S, Yang Q, Bi Z, Chen L, Liu X, et al. Complete sequence and characterization of the paradise fish Macropodus erythropterus (Perciformes: Macropodusinae) mitochondrial genome. Mitochondrial DNA Part B. 2016; 1(1):54-5.

65. Yu P, Yang X, Zhou W, Yang W, Zhou L, Liu X, et al. Comparative mitogenomic and phylogenetic analysis of Apalone spinifera and Apalone ferox (Testudines: Trionychidae). Genetica. 2019;147(2):165-76.

66. Ermini L, Olivieri C, Rizzi E, Corti G, Bonnal R, Soares P, et al. Complete mitochondrial genome sequence of the Tyrolean iceman. Curr Biol. 2008; 18(21):1687-93.

67. Yu P, Ding S, Yang Q, Li X, Wan Q. The complete mitochondrial genome of Sinibotia robusta (Cypriniformes: Cobitidae). Mitochondrial DNA part a, DNA mapping, sequencing, and analysis. Mitochondrial DNA A DNA Mapp Seq Anal. 2016;27(5):3471-2.

68. Kanu UC, Zhao G, Xie P, Li Y, Lei D, Niu J, et al. The complete mtDNA genome of Triplophysa strauchii (Cypriniformes, Balitoridae, Cobitoidea): genome charaterization and phylogenetic analysis. Mitochondrial DNA part a, DNA mapping, sequencing, and analysis. Mitochondrial DNA A DNA Mapp Seq Anal. 2016;27(4):2637-8.

69. Wu J, He Y, Ren H, Zhang Y, Du Z, Xie M, et al. The complete mitochondrial genome sequence of Beaufortia szechuanensis (Cypriniformes, Balitoridae). Mitochondrial DNA part a, DNA mapping, sequencing, and analysis. Mitochondrial DNA A DNA Mapp Seq Anal. 2016;27(4):2535-6.

70. Taanman JW. The mitochondrial genome: structure, transcription, translation and replication. Biochim Biophys Acta. 1999;1410(2):103-23.

71. Mao M, Valerio A, Austin AD, Dowton M, Johnson NF. The first mitochondrial genome for the wasp superfamily Platygastroidea: the egg parasitoid Trissolcus basalis. Genom Natl Res Council Can. 2012;55(3):194-204.

72. Rodovalho Cde M, Lyra ML, Ferro M, Bacci M Jr. The mitochondrial genome of the leaf-cutter ant Atta laevigata: a mitogenome with a large number of intergenic spacers. PLoS One. 2014;9(5):e97117.

73. Ghikas DV, Kouvelis VN, Typas MA. Phylogenetic and biogeographic implications inferred by mitochondrial intergenic region analyses and ITS15.8S-ITS2 of the entomopathogenic fungi Beauveria bassiana and $B$. brongniartii. BMC Microbiol. 2010;10:174.

74. Zhang DX, Hewitt GM. Insect mitochondrial control region: a review of its structure, evolution and usefulness in evolutionary studies. Biochem Syst Ecol. 1997;25(2):99-120.

75. Fonseca MM, Posada D, Harris DJ. Inverted replication of vertebrate mitochondria. Mol Biol Evol. 2008;25(5):805-8. 
76. Rand DM. Endotherms, ectotherms, and mitochondrial genome-size variation. J Mol Evol. 1993;37(3):281-95.

77. Wei SJ, Shi M, Chen XX, Sharkey MJ, van Achterberg C, Ye GY, et al. New views on strand asymmetry in insect mitochondrial genomes. PLoS One. 2010;5(9):e12708

78. Wei SJ, Shi M, Sharkey MJ, van Achterberg C, Chen XX. Comparative mitogenomics of Braconidae (Insecta: hymenoptera) and the phylogenetic utility of mitochondrial genomes with special reference to Holometabolous insects. BMC Genomics. 2010;11:371.

79. Perna NT, Kocher TD. Patterns of nucleotide composition at fourfold degenerate sites of animal mitochondrial genomes. J Mol Evol. 1995;41(3):353-8.

80. Perdices A, Ozeren CS, Erkakan F, Freyhof J. Diversity of spined loaches from asia minor in a phylogenetic context (teleostei: cobitidae). PLoS One. 2018; 13(10):1.

81. Tan XC, Li P, Wu TJ, Yang J. Cobitis xui, a new species of spined loach (Teleostei: Cobitidae) from the Pearl River drainage in southern China. Zootaxa. 2019;4604(1):4601.

82. Saitoh K, Kim IS, Lee EH. Mitochondrial gene introgression between spined loaches via hybridogenesis. Zool Sci. 2004;21(7):795-8.

83. Koizumi N, Takemura T, Watabe K, Mori A. Genetic variation and diversity of Japanese loach inferred from mitochondrial DNA. Transact Japanese Soc Irrigation. 2010;77:7-16.

84. Kitagawa T, Fujii Y, Koizumi N. Origin of the two major distinct mtDNA clades of the Japanese population of the oriental weather loach Misgurnus anguillicaudatus (Teleostei: Cobitidae). Folia Zool. 2011:60(4):343-9.

85. Arai K. Genetics of the loach, Misgurnus anguillicaudatus: recent progress and perspective. Folia Biol (Krakow). 2003;51:107-17.

86. $X J Y, T Z, Y C L, K L, M$ Z. Chromosomes of Chinese freshwater fishes. Beijing: Science Press; 1989.

87. Abbas K, Li MY, Wang WM, Zhou XY. First record of the natural occurrence of hexaploid loach Misgurnus anguillicaudatus in Hubei Province, China. J Fish Biol. 2009;75(2):435-41.

88. Clark MK, Schoenbohm LM, Royden LH, Whipple KX, Burchfiel BC, Zhang X, et al. Surface uplift, tectonics, and erosion of eastern Tibet from large-scale drainage patterns. Tectonics. 2004;23(1):1.

89. Chen Q, Zheng B. Systematic synopsis of chinese fishes, vol. 1. Beijing, China: Reaktion books; 1987.

90. Burland TG. DNASTAR's Lasergene sequence analysis software. Methods Mol Biol. 2000;132:71-91.

91. Bernt M, Donath A, Juhling F, Externbrink F, Florentz C, Fritzsch G, et al. MITOS: improved de novo metazoan mitochondrial genome annotation. Mol Phylogenet Evol. 2013;69(2):313-9.

92. Lowe TM, Chan PP. tRNAscan-SE on-line: integrating search and context for analysis of transfer RNA genes. Nucleic Acids Res. 2016:44(W1):W54-7.

93. Grant JR, Stothard P. The CGView server: a comparative genomics tool for circular genomes. Nucleic Acids Res. 2008;36:W181-4.

94. Crooks GE, Hon G, Chandonia JM, Brenner SE. WebLogo: a sequence logo generator. Genome Res. 2004;14(6):1188-90.

95. Kumar S, Stecher G, Tamura K. MEGA7: molecular evolutionary genetics analysis version 7.0 for bigger datasets. Mol Biol Evol. 2016;33(7):1870-4.

96. Edgar RC. MUSCLE: multiple sequence alignment with high accuracy and high throughput. Nucleic Acids Res. 2004;32(5):1792-7.

97. Zhang D, Gao F, Jakovlic I, Zou H, Zhang J, Li WX, et al. PhyloSuite: an integrated and scalable desktop platform for streamlined molecular sequence data management and evolutionary phylogenetics studies. Mol Ecol Resour. 2020;20(1):348-55.

98. Kalyaanamoorthy S, Minh BQ, Wong TKF, von Haeseler A, Jermiin LS. ModelFinder: fast model selection for accurate phylogenetic estimates. Nat Methods. 2017;14(6):587-9.

99. Stamatakis A. RAxML version 8: a tool for phylogenetic analysis and postanalysis of large phylogenies. Bioinformatics. 2014;30(9):1312-3.

100. Pang S, Stones RJ, Ren MM, Liu XG, Wang G, Xia HJ, et al. V3.1: MrBayes on graphics processing units for protein sequence data. Mol Biol Evol. 2015; 32(9):2496-7.

101. Drummond AJ, Suchard MA, Xie D, Rambaut A. Bayesian phylogenetics with BEAUti and the BEAST 1.7. Mol Biol Evol. 2012;29(8):1969-73.

102. Baele G, Lemey P, Bedford T, Rambaut A, Suchard MA, Alekseyenko AV. Improving the accuracy of demographic and molecular clock mode comparison while accommodating phylogenetic uncertainty. Mol Biol Evol. 2012;29(9):2157-67.
103. Rambaut A, Drummond AJ, Xie D, Baele G, Suchard MA. Posterior summarization in Bayesian Phylogenetics using tracer 1.7. Syst Biol. 2018; 67(5):901-4

\section{Publisher's Note}

Springer Nature remains neutral with regard to jurisdictional claims in published maps and institutional affiliations.
Ready to submit your research? Choose BMC and benefit from:

- fast, convenient online submission

- thorough peer review by experienced researchers in your field

- rapid publication on acceptance

- support for research data, including large and complex data types

- gold Open Access which fosters wider collaboration and increased citations

- maximum visibility for your research: over $100 \mathrm{M}$ website views per year

At $\mathrm{BMC}$, research is always in progress.

Learn more biomedcentral.com/submissions 